\title{
Strategic use of nanotechnology in drug targeting and its consequences on human health: A focused review
}

\author{
ANAND MAURYA ${ }^{1}$, ANURAG KUMAR SINGH ${ }^{2}$, GAURAV MISHRA ${ }^{1}$, KOMAL KUMARI $^{3}$, \\ ARATI RAI ${ }^{4}$, BHUPESH SHARMA $^{5}$, GIRIRAJ T. KULKARNI ${ }^{5}$, RAJENDRA AWASTHI $^{5, *}$ \\ ${ }^{1}$ Faculty of Ayurveda, Department of Medicinal Chemistry, Institute of Medical Sciences, Banaras Hindu University, Varanasi, India \\ ${ }^{2}$ Centre of Experimental Medicine and Surgery, Institute of Medical Sciences, Banaras Hindu University, Varanasi, India \\ ${ }^{3}$ Department of Pharmacy, School of Chemical Sciences and Pharmacy, Central University of Rajasthan, Ajmer, India \\ ${ }^{4}$ Department of Pharmacy, Hygia Institute of Pharmaceutical Education and Research, Lucknow, India \\ ${ }^{5}$ Amity Institute of Pharmacy, Amity University, Noida, India \\ *Corresponding author: Dr. Rajendra Awasthi; Amity Institute of Pharmacy, Amity University, Sector 125, Noida 201303, Uttar Pradesh, India; \\ Phone: +91 94592 34530; Fax: +91 120243 1870; E-mail: awasthi02@gmail.com
}

(Received: July 25, 2018; Revised manuscript received: January 3, 2019; Accepted: January 28, 2019)

\begin{abstract}
Since the development of first lipid-based nanocarrier system, about $15 \%$ of the present pharmaceutical market uses nanomedicines to achieve medical benefits. Nanotechnology is an advanced area to meliorate the delivery of compounds for improved medical diagnosis and curing disease. Nanomedicines are gaining significant interest due to the ultra small size and large surface area to mass ratio. In this review, we discuss the potential of nanotechnology in delivering of active moieties for the disease therapy including their toxicity evidences. This communication will help the formulation scientists in understanding and exploring the new aspects of nanotechnology in the field of nanomedicine.
\end{abstract}

Keywords: nanomedicines, nanocarriers, nanotechnology, nanoformulation, toxicity

\section{Introduction}

Nanoparticles (NPs) are nanosized colloidal particles, in which a drug is encapsulated, entrapped, or attached to the NPs matrix (Fig. 1). The NP production approaches can be divided into two major categories based on whether the synthesis requires a polymerization reaction or is direct from a preformed polymer or macromolecule [1]. The choice of production approach depends on the nature of polymers as well as on the drug to be encapsulated. NPs have been extensively investigated for oral delivery of drugs, because these tiny particles can protect the drug against enzymatic and hydrolytic degradation in the gastrointestinal tract (GIT), prolong the residence time in the gut by mucoadhesion, and notably improve the bioavailability of drugs $[2,3]$. Increased oral bioavailability has been reported in case of the anticancer drugs that are delivered through nanocarrier [4]. The in vivo bioavailability of paclitaxel was reported to be increased by 10 times when compared to orally administered Taxol $^{\circledR}[5]$.

Polymeric materials have the best combination of characteristics as these are stable and allow higher loading of drugs, provide control over drug release kinetics, can be readily modified to display a variety of surface-attached ligands, and are safe for human use [6]. A variety of biodegradable and non-biodegradable polymeric nanocarriers employed for oral drug delivery are presented in Table I. Industries investing in the development of different types of nanoformulations and undergoing clinical trials are presented in Table II.

\section{Poly (lactic-co-glycolic acid) NPs}

NPs based on poly (lactic-co-glycolic acid; PLGA) have been extensively studied as therapeutic delivery vehicles

This is an open-access article distributed under the terms of the Creative Commons Attribution-NonCommercial 4.0 International License, which permits unrestricted use, distribution, and reproduction in any medium for non-commercial purposes, provided the original author and source are credited, a link to the CC License is provided, and changes - if any - are indicated. 


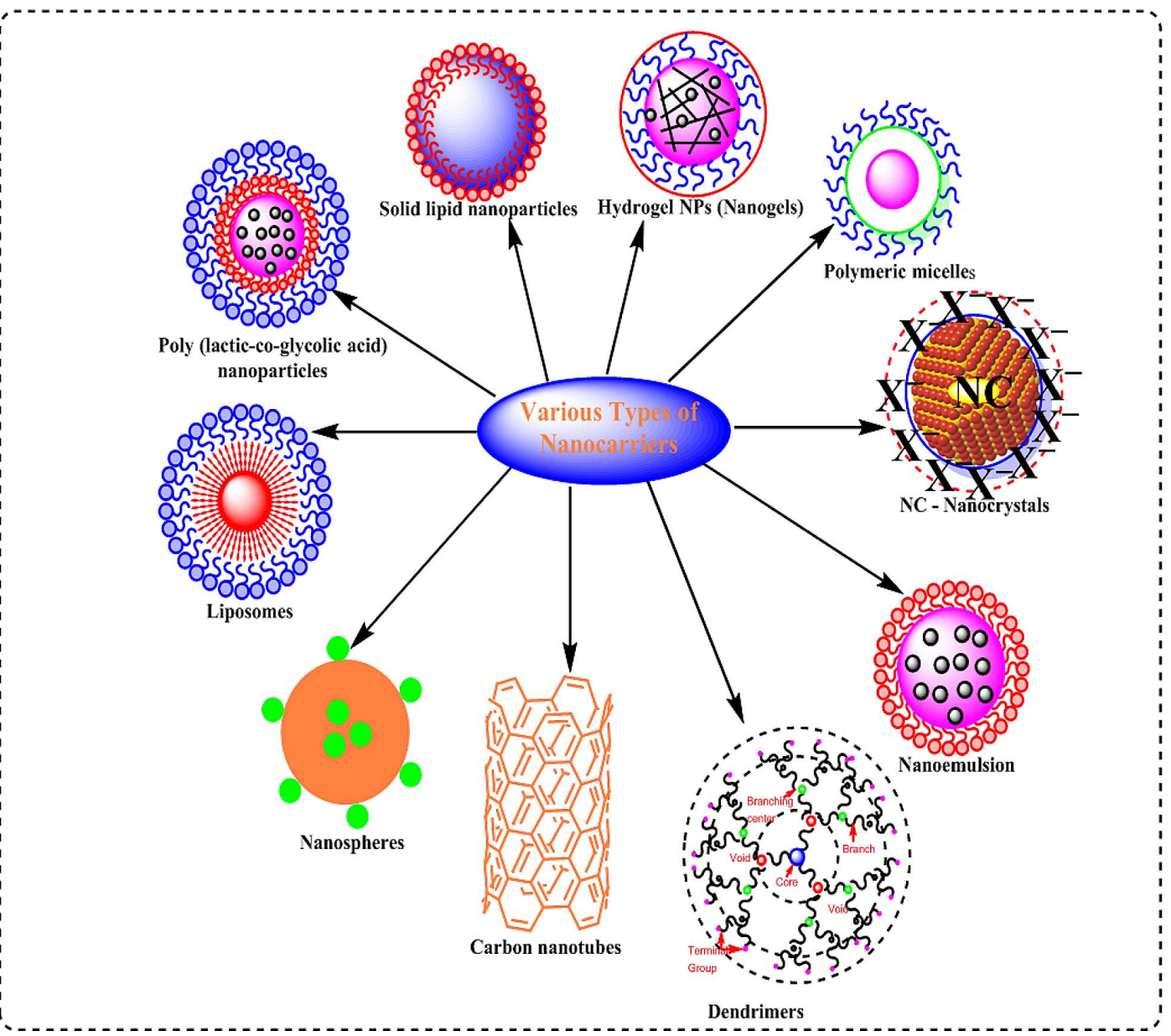

Fig. 1. Schematic representation of a various multifunctional nanocarriers

for many bioactives owing to their biodegradability and biocompatibility. PLGA microparticles have received approval from the US-FDA for establishing sustained release of leuprolide (Lupron Depot ${ }^{\circledR}$, AbbVie Inc., North Chicago, IL, USA) and triptorelin (Trelstar ${ }^{\circledR}$, Allergan, Inc., Dublin, Ireland) [22]. PLGA NPs have shown the ability to improve oral bioavailability of drugs with low solubility such as paclitaxel and curcumin $[3,7]$. Xie and co-workers synthesized curcumin-loaded PLGA NPs by a solid-in-oil-in-water solvent evaporation method. The results showed $91.96 \%$ entrapment and $5.75 \%$ loading of curcumin in NPs. The water solubility of curcumin was increased $\sim 640$-fold from the prepared PLGA NPs when compared to that of pure curcumin. The PLGA NPs resulted in an improved oral bioavailability (5.6-fold) and half-life of curcumin compared with that of pure curcumin. The improved oral bioavailability of curcumin might be associated with improved solubility due to the increased effective surface area of NPs [23]. Sustained in vivo release of orally administered cyclosporine from PLGA NPs has been reported to have decreased cyclosporine-associated nephrotoxicity. However, Sandimmune Neoral, a commercially available formulation, failed to achieve both $[24,25]$.

\section{Solid lipid nanoparticles}

Solid lipid nanoparticles (SLNs) are lipid-based effective and safe alternate to the existing therapeutics. These tiny particles are free from the potential toxicities of polymeric NPs [26]. These particles have better stability profile in the upper GIT when compared to other lipid nanocarriers. Significant efforts have been made in recent years to improve the bioavailability of various drugs, such as insulin, bufalin, risperidone, and puerarin $[8,17$, 26-28]. Luo et al. reported improved oral bioavailability of puerarin loaded in SLNs. The results suggested rapid and improved ( $>3$-fold) oral absorption of puerarin from SLNs when compared to puerarin suspension. The study supported the fact that these lipid-containing tiny particles are promising drug-delivery vehicle for the enhancement of oral bioavailability of BCS class II drugs [29].

\section{Hydrogel NPs (nanogels)}

Hydrogel NPs (nanogels), a family of nanoscale particulate materials, have shown benefits in oral delivery of drugs over other commercially available drug-delivery 
Table I Types of nanocarriers conjugated with drug and their effect on pharmacological property

\begin{tabular}{|c|c|c|c|c|c|}
\hline Nanocarriers & Drug used & Pharmacological effect & $\begin{array}{l}\text { Size } \\
(\mathrm{nm})\end{array}$ & Composition & Ref. \\
\hline Polymeric NPs & Curcumin & $\begin{array}{l}\text { Water solubility of curcumin was increased } \\
\text { about } 640 \text {-fold relative to pure curcumin. Oral } \\
\text { bioavailability was increased } 5.6 \text {-fold for longer } \\
\text { duration compared with that of pure curcumin }\end{array}$ & - & PLGA & {$[7]$} \\
\hline Solid lipid NPs & Puerarin & $\begin{array}{l}\text { The relative bioavailability of puerarin from } \\
\text { SLN was increased to } 43 \text {-fold }\end{array}$ & - & - & {$[8]$} \\
\hline $\begin{array}{l}\text { Hydrogel NPs } \\
\text { (nanogels) for } \\
\text { oral drug } \\
\text { delivery }\end{array}$ & Silymarin & $\begin{array}{l}\text { The developed carrier was biodegradable and } \\
\text { enhanced oral bioavailability of silymarin for } \\
\text { prolonged time period }\end{array}$ & $10-100$ & PLGA & [9] \\
\hline $\begin{array}{l}\text { Polymeric } \\
\text { micelles }\end{array}$ & Paclitaxel & $\begin{array}{l}\text { The oral bioavailability of paclitaxel from } \\
\text { polymeric micelles was estimated at } 12.4 \%\end{array}$ & $85-90$ & $\begin{array}{l}\text { PEG-b-P } \\
\text { (VBODENA } \\
\text { co-AA)y }\end{array}$ & {$[10,11]$} \\
\hline $\begin{array}{l}\text { Liposomes in } \\
\text { oral drug } \\
\text { delivery }\end{array}$ & $\begin{array}{l}\text { Somatostatin } \\
\text { analog octreotide }\end{array}$ & $\begin{array}{l}\text { Mild and prolonged hypoglycemic effect was } \\
\text { elicited following oral administration. Plasma } \\
\text { insulin level was increased for } 20 \mathrm{~h}\end{array}$ & - & $\begin{array}{l}\text { Tetraether lipids } \\
\text { derived from } \\
\text { archaea bacteria }\end{array}$ & {$[12,13]$} \\
\hline $\begin{array}{l}\text { Nanoemulsion } \\
\text { and self- } \\
\text { nanoemulsifying } \\
\text { drug-delivery } \\
\text { system for oral } \\
\text { drug delivery }\end{array}$ & Curcumin & $\begin{array}{l}\text { Aqueous solubility of curcumin increased to } \\
\text { about } 6,000,000 \text {-fold. }\end{array}$ & $<100$ & $\begin{array}{l}\text { A folate-modified } \\
\text { SNEDDS }\end{array}$ & {$[14,15]$} \\
\hline Nanocrystals & $\begin{array}{l}\text { Coenzyme Q10 } \\
\quad(\text { CoQ10) }\end{array}$ & $\begin{array}{l}\text { CoQ10 dissolution enhanced and the oral } \\
\text { bioavailability of CoQ } 10 \text { was } \sim 2.5 \text {-fold higher } \\
\text { from nanocrystals than coarse suspensions }\end{array}$ & $<500$ & - & {$[16]$} \\
\hline Dendrimers & $\begin{array}{l}\text { Short hairpin } \\
\text { RNA }\end{array}$ & $\begin{array}{l}\text { RNAi-mediated hTERT gene silencing } \\
\text { coupled with dendrimer delivery would be a } \\
\text { promising approach for the management of } \\
\text { oral cancer }\end{array}$ & $107-315$ & PAMAM & {$[17]$} \\
\hline Nanospheres & Cyclosporine A & $\begin{array}{l}\text { Eudragit }^{\circledR} \text { S100-based nanospheres of } \\
\text { cyclosporine A showed improved } \\
\text { bioavailability of cyclosporine A compared to } \\
\text { the Neoral }{ }^{\circledR} \text { microemulsion }\end{array}$ & $100-200$ & $\begin{array}{c}\text { Eudragit }{ }^{\circledR} \text {-based } \\
\text { nanospheres }\end{array}$ & {$[18]$} \\
\hline $\begin{array}{l}\text { Carbon } \\
\text { nanotubes }\end{array}$ & $\begin{array}{l}\text { Cyclo- } \\
\text { (D-tryptophan- } \\
\text { tyrosine) peptide }\end{array}$ & $\begin{array}{l}\text { The developed carbon nanotubes delivered } \\
\text { gene to the duodenum, stomach, liver, and } \\
\text { kidney via oral route }\end{array}$ & - & $\begin{array}{l}\text { Carbon cylinders } \\
\text { composed of } \\
\text { benzene rings }\end{array}$ & [19] \\
\hline
\end{tabular}

NP: nanoparticle; PLGA: poly lactic-co-glycolic acid; PAMAM: polyamidoamine; SNEDDS: self-nanoemulsifying drug delivery system; PEG: polyethylene glycol

systems [30]. Interestingly, hydrogel nanoparticulate materials demonstrate the simultaneous characteristics of hydrogels and NPs, such as hydrophilicity, flexibility, versatility, and high water absorptivity [30, 31]. Nanogels with a three-dimensional (3D) network structure and a diameter of 10-100 nm have some smart functional properties such as $\mathrm{pH}$-sensitivity and/or temperature-sensitivity, etc. [32-35]. As a representative for oral drug delivery of nanogels, El-Sherbiny et al. [9] reported a biodegradable $\mathrm{pH}$-responsive silymarin-loaded alginate-PLGA nanogel for oral delivery of silymarin, a hydrophobic natural therapeutic drug. In another study, silymarin-loaded PLGA NPs were prepared using singleemulsion solvent evaporation method. Aqueous solution of sodium alginate containing PLGA NPs was used to make $\mathrm{pH}$-sensitive hydrogel NPs through ionotropic cross-linking. The resultant nanogel was biodegradable that could sustain the release profile and enhance the oral bioavailability of silymarin [36].

\section{Polymeric micelles (PMs)}

Micelles are amphiphilic polymer and surfactant-based self-assembled particles $(\sim 20-100 \mathrm{~nm})$. PMs are the 
Table II Companies investing in the development of different types of nanoformulations and undergoing clinical trials [20, 21]

\begin{tabular}{|c|c|c|c|c|}
\hline $\begin{array}{l}\text { Drug } \\
\text { product }\end{array}$ & Active constituents/formulation & Therapeutic use & Manufacturer & Status \\
\hline LEP-ETU & Liposomal paclitaxel & Breast/lung cancers & Neopharma & Phase I/II \\
\hline Onco-TCS & Liposomal vincristine & Non-Hodgkin lymphoma & Inex & Phase I/II \\
\hline Aroplatin & Liposomal cisplatin analog & Colorectal cancer & Antigenics & Phase I/II \\
\hline SPI-77 & Stealth liposomal cisplatin & Head and neck cancer & Alza & Phase III \\
\hline OSI-211 & Liposomal lurtotecan & Lung cancer/recurrent ovarian & OSI & Phase II \\
\hline EndoTAG-I & Paclitaxel & Pancreatic cancer & $\begin{array}{l}\text { Medigene/SynCore } \\
\text { Biotechnology }\end{array}$ & Phase II \\
\hline ThermoDox & Doxorubicin & Hepatocellular carcinoma & Celsion Corporation & Phase III \\
\hline Atragen & Liposomal all transretinoic acid & Acute promyelocytic leukemia & Aronex Pharmaceuticals & Phase II \\
\hline Auroshell & Gold nanoshells & Aurolace therapy of cancer & Nanospectra Biosciences & Phase 1 \\
\hline NKTR-105 & PEG-docetaxel & Solid tumors & Nektar Therapeutics & Phase I \\
\hline AMG223 & Phosphate-binding polymer & $\begin{array}{l}\text { Hyperphosphatemia in CKD patients } \\
\text { on hemodialysis }\end{array}$ & Amgen & Phase II \\
\hline NKTR-118 & PEG-naloxone & Opioid-induced constipation & Nektar & Phase II \\
\hline $\begin{array}{l}\text { SLIT } \\
\text { cisplatin }\end{array}$ & Liposomes & Lung cancer & Transave & Phase II \\
\hline
\end{tabular}

CKD: chronic kidney disease; PEG: polyethylene glycol; SLIT: sustained release lipid inhalation targeting

choice of delivery vehicle for the drugs, which are hydrophobic in nature and exhibit poor bioavailability. The stability and bioavailability of poorly water-soluble drugs can be enhanced by incorporating drug into the inner hydrophobic core [25, 37]. Extensive efforts have been made in the development of PMs for intravenous administration of drugs because they avoid hepatic first-pass metabolism and easily reach the lesion sites [38]. Improved oral bioavailability of hydrophobic drugs has been reported using PMs [10, 39]. PMs are the most promising entities for the delivery of paclitaxel. The bioavailability from intravenous route was eightfold higher than oral route [11]; while in another study, $6.5 \%$ oral bioavailability of Taxol has been reported through Cremophor EL micelles [40].

\section{Liposomes}

Liposomes are microscopic lipid bilayer vesicles that have been studied extensively as potential drug carriers [41]. In 1964, Bangham et al. disclosed the first electron microscopic images of such lipid bilayered spherical vesicles surrounded by an amphiphilic phospholipid membrane [1]. They are composed of phosphatidylcholine and phosphatidyl ethanolamine. Cholesterol is used to modify the lipid membrane rigidity to make it capable of encapsulating hydrophobic and hydrophilic drugs. The membrane permeability and cellular absorption of proteins, peptides, and hydrophilic drugs can be improved through liposomal vesicles. High molecular weight of these drugs leads to their degradation in the GIT and poor absorption $[42,43]$. Liposomes have low toxicity, can entrap structurally diverse drugs, and have properties similar to the biological membrane. However, success of orally stable lipid vesicles is limited due to the chemical and enzymatic destabilization. Polymer-coated liposomes have been extensively investigated to defeat the stability issues, extend the residence time in the GIT, and improve oral efficiency of liposomal delivery systems [44].

\section{Nanoemulsion and self-nanoemulsifying system}

During the past 2-3 decades, attention has been given on the development of nanoemulsions and selfnanoemulsifying drug-delivery system (SNEDDS) to improve the oral bioavailability of BCS class II drugs [45]. The improved oral bioavailability of drugs from these systems could be due to the increased solubilization and protection of drug from enzymatic and physicochemical degradation. Small droplet size increases the interface between the aqueous gut medium and lipophilic droplets, which leads to homogeneous and wide distribution of drug throughout the GIT $[25,46]$. Presence of large amount of surfactants in SNEDDS may alter the membrane permeability, which leads to the GI side effects [47].

\section{Nanoemulsions for oral drug delivery}

These are thermodynamically stable drug carriers with the droplet size usually $<100 \mathrm{~nm}$. Nanoemulsions have been explored to increase the oral bioavailability of water insoluble drugs [48]. Parveen et al. reported improved 
bioavailability of silymarin from oil-in-water $(\mathrm{o} / \mathrm{w})$-based nanocarrier system. The results of in vivo study demonstrated fourfold area under the curve and sixfold $C_{\max }$ of silymarin from orally administered nanoemulsion than those of conventional silymarin suspension [49]. Bali et al. constructed pseudoternary phase diagrams to investigate the effect surfactants and co-surfactants in nanoemulsion formulation of ezetimibe. The results revealed significant improvement in absorption of ezetimibe from nanoemulsion when compared to the conventional tablet (Ezedoc ${ }^{\circledR} 10$, ezetimibe $10 \mathrm{mg}$ ) [50].

\section{Self-nanoemulsifying drug-delivery system (SNEDDS)}

Emulsion systems are associated with their own complications, including stability and manufacturing constraints associated with their commercial production. Self-emulsifying drug-delivery system (SEDDS) can overcome the problems associated with conventional emulsion systems. The droplet size of SEDDS ranges from 20 to $200 \mathrm{~nm}$. These droplets provide a large surface area for the absorption of dissolved drugs $[25,51,52]$. SNEDDS, globule size range $<100 \mathrm{~nm}$, is thermodynamically and isotropically stable solution consisting of oil, surfactant, co-surfactant, and drug, which can spontaneously produce $\mathrm{o} / \mathrm{w}$ nanoemulsion when mixed with water under mild stirring $[14,45,53]$. At present, four SEDDSbased commercial drug products, such as Sandimmune ${ }^{\circledR}$ (cyclosporine A), Sandimmun $\mathrm{Neoral}^{\circledR}$ (cyclosporine A), Norvir $^{\circledR}$ (ritonavir), and Fortovase ${ }^{\circledR}$ (saquinavir), are available in the pharmaceutical market [54]. Although several SEDDS formulations are approved by FDA, in vivo performance of SNEDDS formulations using in vitro data is still in its prediction of infancy [55]. SNEDDS showed multiple absorption mechanisms, such as passive diffusion, active transport, paracellular, endocytosis, and P-glycoprotein-mediated absorption. Thus, a singlemechanism in vitro study (such as dissolution or permeability) might not be appropriate for evaluating the in vivo-in vitro correlation of SNEDDS formulations [56]. Care should be taken when prioritizing SNEDDS to use in humans [57]. Recently, much attention has been given for the development of SNEDDS to improve the solubility, dissolution, and oral absorption of poorly water-soluble drugs, such as apigenin, gemfibrozil, and coenzyme Q10 (CoQ10) and zedoary essential oil [58-61]. Improved oral bioavailability of tamoxifen citrate-loaded SNEDDS has been reported for the treatment of breast cancer. The study revealed complete drug release after $6 \mathrm{~h}$ dissolution study in phosphate buffer ( $\mathrm{pH}$ 7.4) [62].

\section{Nanocrystals}

By definition, nanocrystals are $<1 \mu \mathrm{m}$ size particles, but practically their size is $\sim 500 \mathrm{~nm}$. Nanocrystals are prepared by top-down or bottom-up approach with complete drug loading $[25,63]$. They do not have any carrier material and may be formulated as suspensions or more frequently as dry dosage forms (tablets and capsules) [64]. A range of oral nanocrystal formulations is available including Emend ${ }^{\circledR}$ (aprepitant), Rapamune ${ }^{\circledR}$ (rapamycin), Megace ES $^{\circledR}$ (Megestrol), Triglide ${ }^{\circledR}$ (fenofibrate), and TriCor ${ }^{\circledR}$ (fenofibrate) [65]. The combination of dose of panzem nanocrystals and temozolomide in patients with recurrent glioblastoma multiforme is under Phase II investigation [66]. Nanocrystal syntheses do not require surfactant such as cremophor EL. Therapeutic relevance of nanocrystals is due to the increased dissolution rates, saturation velocity, and improved adhesion to cell membranes. Piao et al. investigated dissolution profiles of CoQ10 in nanocrystals and its oral absorption in rats and compared with a coarse suspension of CoQ10. In case of nanocrystals, an increase in dissolution profile of CoQ10 was observed and the in vivo study in rats demonstrated that the oral bioavailability of nanocrystals was $\sim 2.5$-fold higher than that of coarse suspensions. When the compounds exhibit dissolution rate-limited bioavailability, the nanocrystals can lead to better bioavailability. However, this approach can add tremendous dosing flexibility for other administration routes, especially when highly concentrated formulations are needed [16].

\section{Dendrimers}

Dendrimers ( $<10 \mathrm{~nm}$ size) are highly branched 3D treelike molecules comprising a core, branches, and end groups prepared using monomeric or oligomeric units such as melamine, polyamidoamine (PAMAM), polypropyleneimine (PPI), poly(L-glutamic acid), and polyaryl ether $[1,67]$. Dendrimer size can progressively increase with an addition of each generation (shell) of branches and can be built from a molecular level to nanoscale size (1-10 nm) [68, 69]. Drug molecules can be attached to the functional groups on dendrimer surface or shielded in the dendritic channels of the interior environment of the sphere. Potential use of PAMAM dendrimers in oral drug delivery has been evaluated by Sadekar and Ghandehari [70]. It has been proved that PAMAM dendrimers are transported by a combination of transcellular and paracellular routes [71]. Depending on the surface chemistry, PAMAM dendrimers can open the tight junctions of epithelial barriers. In 2008, Ke et al. [72] developed drug-PAMAM complex for oral administration and demonstrated a significant increase in oral bioavailability (200-fold) over that the free drug. However, most of the reports are based on the extent of in vitro drug absorption from dendrimers. No direct in vivo evidence of dendrimer permeability after oral administration has been reported [73]. 


\section{Nanospheres}

Nanospheres are spherical structures composed of a matrix system in which drug is distributed by entrapment, attachment, or encapsulation. These are typically larger than micelles having diameters between 100 and $200 \mathrm{~nm}$, which can be used for oral applications [74]. Wang et al. [18] reported improved bioavailability of cyclosporine A from nanospheres prepared using Eudragit ${ }^{\circledR}$ S100 when compared to the Neoral ${ }^{\circledR}$ microemulsion system. The increase in absorption was attributed to a shorter transit time in the stomach, greater bioadhesiveness, and better protection against degradation.

\section{Carbon nanotubes (CNTs)}

CNTs are carbon cylinders composed of benzene rings. These are carbon-structured tubes that can be single or multiwalled. CNTs have attracted tremendous attention of pharmaceutical scientists both from the academia and industries regarding their biomedical applications. Application of CNTs for the oral delivery of drugs has evoked great interest. Hsieh et al. [19] developed cyclo-(D-tryptophan-tyrosine) peptide nanotubes, which can deliver gene to duodenum, stomach, liver, and kidney through oral administration.

\section{Quantum dots}

Quantum dots are derived from heterogeneous group of NPs containing 1,000-100,000 molecules and demonstrating uncommon quantum effects [75]. It facilitates the absorption, distribution, metabolism, and excretion. The toxicity of quantum dots has been quantified from environmental conditions and inherent physicochemical properties. Their size depends on coating thickness, which varies from 2.5 up to $100 \mathrm{~nm}$.

\section{General Toxic Behavior of NPs}

In the present scientific era, nanotechnology is gaining popularity in biology, chemistry, or any other fields. Since the introduction of first lipid-based nanodrug carrier, the continued success of nanotechnology in the healthcare system has led to the birth of nanomedicine [76]. The nanotechnology has been associated with many novel things, which are highly promising. There are many questions being raised regarding the safety of nanomaterials. To date, scientists do not know how much toxic the nanomaterials are and what is the intensity of toxicity [77]. It has been proved that the NPs are more reactive and toxic in nature $[1,76]$. To understand the toxic effects of NPs, different research groups are working on this aspect using cell line studies, incubation, etc. [78]. Many drugs delivered by incorporating into NPs have shown evidence of reduced toxicity of the drug by lowering its dose and targeting the delivery to the site of action [79]. However, this is not sufficient for the nanoformulations to be considered as safe for human use. To access the toxicity caused by nanoformulations, the toxicity study must be carried out for NPs formulated with and without drug. This comparative study will help the formulation scientists to identify the toxicity caused by the blank or unloaded nanoformulation. Various approaches have been reported to investigate the toxicity of the nanoformulations. There are many evidences that quote the solid toxicological behavior of the prepared NPs. The toxicological issues associated with interaction of nanoformulations within the host cell are mainly governed by the particle size, surface area, shape, and agglomeration. Particle size is the major factor that might cause danger to human health [1]. Table III presents particle types and its description about cause of toxicity.

\section{Evidences regarding the toxicity of nanoformulations}

Bahadar et al. [80] reviewed the toxicological data of NPs in human health. The nanosized particles have greater lung deposition and rapid systemic translocation having various inflammatory, oxidative, and cytotoxic effects than larger particles [1]. The process of deposition of inhaled carbon NPs in the lungs is known as lung burden. It is evident that elimination of CNTs from the lungs is slower and causes lung burden (e.g., inflammation and

Table III Particle types and its description about cause of toxicity

$\begin{array}{ll}\begin{array}{l}\text { Particle type } \\ \mathrm{P}_{10} \text { and } \mathrm{P}_{2.5}\end{array} & \text { The mass fraction of the particle with average diameter } 10 \text { and } 2.5 \mu \mathrm{m} \text {, respect } \\ \text { Ultrafine } & \text { The fraction of } \mathrm{P}_{10} \text { in size ranges } 0.1 \mu \mathrm{m} \text { and contains primary particle as well as } \\ \text { particles } & \\ \text { Coarse particles } & \text { The size of such particle is } 2.5 \mu \mathrm{m} \text { and they are mass fraction of particle } \mathrm{P}_{10} \\ \text { PSP } & \text { Low specific toxicity and less soluble, it is fine or ultrafine particle } \\ \text { DEP } & \text { Diesel exhaust particles } \\ \text { CDNP } & \text { Diesel exhaust particles are combustion-derived nanoparticles }\end{array}$

PSP: polyamide seeding particle 
granuloma formation) $[76,81]$. Toxicity can also be generated by the direct inhalation of the particle $\mathrm{P}_{10}$ (particles of size ranging $10 \mathrm{~mm}$ or less than that). Therefore, there is a need to discuss the toxicity behavior of such modified nanoformulation [82]. Generally, most of the mass of $\mathrm{P}_{10}$ is considered to be harmless in nature, but it is evident that the particle $\mathrm{P}_{10}$ is responsible for the pro-inflammatory effects [83]. $\mathrm{P}_{10}$ is also implicated in causing adverse effects, which is supported by the substantial toxicological data [84]. Due to the nanosize, the surface area per unit mass is very high and this is the causative factor for higher toxicity in comparison to particles with the low surface area [85]. There are many constituents found within the $\mathrm{P}_{10}$, which are not much toxic. There are many deaths occurring due to the cardiovascular diseases and respiratory-related diseases [86]. Inflammation is a very common factor causing adverse effects and is an important property of NP toxicity [87]. There are many evidences confirming inflammatory effects of NPs [88].

The mentioned reports elucidating the toxicity behavior of nanomaterials also conclude that most of the adverse health concerns are associated with the particulate matter, and can be measured as exacerbations of respiratory disease [89]. It is through the pulmonary inflammation and distribution of ultrafine ambient particles (Fig. 2).

\section{Statistics showing toxicological effect of nanoformulations}

\section{Carbon nanotubes (CNTs)}

CNTs were discovered as novel class of multifunctional nano structures. CNTs are potential to act as biopersistent fibers. In vitro cultivation of keratinocytes or bronchial epithelial cells with high doses of single-walled CNTs leads to generation of reactive oxygen species (ROS), oxidative imbalance, mitochondrial dysfunction, and modifications in the morphology of the cell $[90,91]$. An increased attachment of platelets has been reported with single and multiwall CNTs. Fullerenes $\left(\mathrm{C}_{60}\right)$ are applied as building blocks for these CNTs [92]. Multiwalled CNTs also provoke a pro-inflammatory effect in keratinocytes [93]. Various studies using intratracheal instillation of high-dose nanotubes in rodents expressed chronic lung infection, including interstitial fibrosis and foreign-body granuloma formation $[94,95]$. On the basis of dose per mass, nanotubes are more toxic than quartz particles $[94,96]$. A high dose of aggregated nanotubes and metal impurities is responsible for artificial toxicity.

\section{Fullerenes}

Fullerene (carbon nanostructure $-\mathrm{C}_{60}$ ) was discovered in 1985 by Kroto et al. [97]. Over the past several years, great interest has developed in the potential use of fullerenes in biomedicine [98]. Potential applications of fullerenes are due to their unique free radical chemistry and antioxidant properties. Fullerenes may induce toxicity in presence of light due to surface excitation, which leads to singlet oxygen sensitizer state [99]. With fullerenes, various studies are published based on ecotoxicity of nanomaterials [100]. Uncoated and water-soluble colloidal fullerenes had 48 h LC50 in Daphnia magna ranging from 460 to $800 \mathrm{ppb}[98,99]$. However, in case of sonicated $\mathrm{C}_{60}$ fullerenes, the LC50 was higher with 7.9 ppm [101]. No mortality has been reported in largemouth bass. However, lipid peroxidation and glutathione depletion were observed in brain and gill, respectively, after exposure to $0.5 \mathrm{ppm}_{60}$ fullerenes for $48 \mathrm{~h}$ [102].

\section{Dendrimers}

Regardless of wide biomedical applications of dendrimers, toxicity associated due to terminal- $\mathrm{NH}_{2}$ groups and surface cationic charge, the evidence for successful dendrimers remains limited for clinical applications. The in vitro cytotoxicity of PPI, PAMAM, and poly-L-lysine dendrimers has been reported due to their surface cationic groups $[1,103]$. The cationic terminal groups of dendrimers interact with RBCs and lead to hemolysis [104]. Cationic melamine dendrimers having surface groups like amine, guanidine, carboxylate, sulfonate, or phosphonate are more cytotoxic than anionic or PEGylated dendrimers [105]. Cytotoxicity of PAMAM dendrimers in Caco-2 cell lines [106] and cytotoxicity of PPI and PAMAM dendrimers in $\mathrm{Bl} 6 \mathrm{Fl} 0, \mathrm{CCRF}$, and HepG2 cancer cell lines [107] have been reported. Numerous studies have examined that cationic dendrimers interact with negatively charged biological membrane to produce nanoscale holes and cell lysis [108-112]. The mechanism of cationic PAMAM dendrimer induced membrane damage using 1,2-dimyristoyl-sn-glycero-3-phosphocholine lipid bilayers, and $\mathrm{KB}$ and Rat 2 cells in culture have been reported by Hong et al. [113].

\section{Quantum dots}

Studies expressed that quantum dots exhibit less toxicity [75]. In vitro studies showed that quantum dots may be toxic [114-116] and the toxicity can spread with surface coating [114, 117]. Choi et al. [118] concluded that quantum dot toxicity was decreased by surface modification with $\mathrm{N}$-acetylcysteine, in comparison to nonmodified cadmium telluride quantum dots. Cytotoxicity of naked quantum dots could be due to the impairment of ROS and damage to the plasma membrane, nuclease, and mitochondria [119]. The core substance of cadmiumcontaining quantum dots has toxic potential due to release of highly toxic-free cadmium ions [120, 121]. Cadmium telluride quantum dots cause cell death via mechanisms involving $\mathrm{ROS}$ and $\mathrm{Cd}^{2+}$ accompanied by lysosomal enlargement and intracellular redistribution [122]. Hardman suggested that all quantum dots are not uniform group of substances. Pharmacokinetic profile and toxicity properties of quantum dots depend on inherent physicochemical properties and environmental 


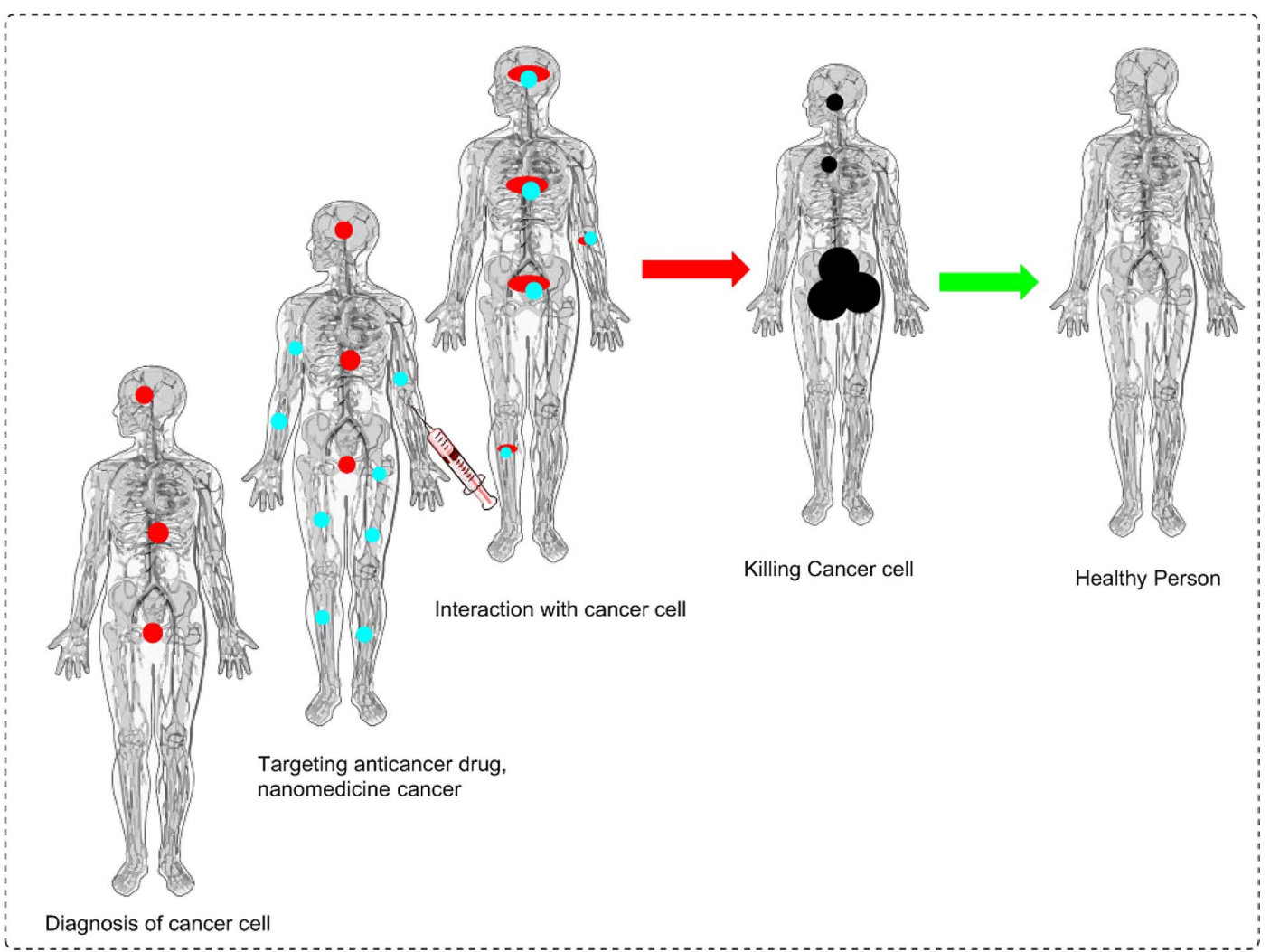

Fig. 2. Diagnosis and targeting of cancer cells using emerging nanoparticle

conditions. The toxicity of quantum dots depends on their size, surface charge, capping material, and functional groups of outer coating, oxidative, photolytic, and mechanical stability [75].

\section{Gold NP/nanoshells}

A joint evaluation of Food and Agriculture Organization of the United Nation and World Health Organization Expert committee on Food Additives (JECFA) suggested that the gold does not show hazard when used as food additive and coloring agent (2001). However, this information was not considered in nanoformulation of gold. Metallic gold NPs can be synthesized in different forms and in different size ranges [123, 124]. In health science, they are used as potential carriers of drug delivery, imaging of cell structure, and their development [125], and for the design of novel cancer therapy products [126-130]. The cytotoxic effect of gold NP was considered in the presence of stabilizer cetyltrimethylammonium bromide $(\mathrm{CTAB})$. Removing the excess CTAB with polyethylene glycol (PEG)-modified gold nanorods did not show the toxicity [131]. Gold solution is used in magnetic resonance imaging by preparation of nanoshells composed of gold and copper, or gold and silver to function as contrast media in diagnostic agent [132] and also used gold-silica for photothermal ablation of tumor cells $[133,134]$. Positive in vivo results were obtained in mouse treated by intravenous administration of PEGcoated gold nanoshells in presence of photothermal ablation [129].

Silica

The size of 15- and 46-nm silica NP showed similar dose-dependent cytotoxicity in vitro. The toxicity of silica NPs increases with an increase in dose and exposure time [135]. Chang et al. [136] stated that silica NPs are toxic at high dosages due to the reduction in cell viability and by lactate dehydrogenase $(\mathrm{LDH})$ release from the cells indicating membrane damage. It has been observed that the concentration above $0.1 \mathrm{mg} / \mathrm{ml}$ significantly reduces cell viability. Alveolar macrophage cell line has been reported to be more liable for NP-induced cytotoxicity than a lung epithelial cell line (A549). This could be due to the phagocytic properties of the macrophage cell line [137]. In another process, the contrast for cationic silica NPs using amino-hexyl-amino propyltrimethoxysilane as a surface modifier reduced the cell toxicity [138]. Various marketed nanoformulation are presented in Table IV.

\section{Natural Bioactives Delivered Through Nanocarrier}

Green nanotechnology is gaining worldwide importance because of exclusion of harmful chemicals, economical 
Table IV List of various marketed nanoformulations

\begin{tabular}{lccc} 
Nanoformulation & Active constituents & Therapeutic use & Name of company \\
Silicon-coated iron oxide & Ferumoxsil & Imaging contrast agents & AMAG Pharmaceuticals \\
Nanocrystal particles & Aprepitant & Antiemetic & Merck \\
Phosphate-binding polymer & Sevelamer & Renal failure & Genzyme (Daiichi licensed) \\
Nanocrystal particles & Sirolimus & Immunosuppressive & Pfizer/Wyeth \\
Nanocrystal particles & Fenofibrate & Hypercholesterolemia & ScielePharma \\
Cholesterol-binding polymer & Welchol & Type 2 diabetes & Genzyme \\
Nanocrystal particles & Megestrol & Antianoretic & Par Pharmaceuticals \\
\hline
\end{tabular}

and use of different eukaryotic and prokaryotic organisms. Among these, the plant extracts act as reducing and capping agents for the NP synthesis, and the resultant prefabricated NPs exhibit better bioactivity [139, 140].

\section{Resveratrol}

Resveratrol (3,5,4'-trihydroxy-trans-stilbene) contains phenol and acts as a phytoalexin protector from external source such as bacteria and fungi. Resveratrol is the best antioxidant [141]. The anticancer activity of resveratrol has been reported for the prevention of skin cancer development in mice [140, 142]. Tremendous efforts have been made to use resveratrol as an anticancer agent in various cancer models, including skin cancer [143-145], breast cancer [146-148], fibrosarcoma $[149,150]$, lung cancer $[151,152]$, gastric and colorectal cancer [153], prostate cancer [154, 155], hepatoma [156, 157], neuroblastoma [158], pancreatic cancer $[159,160]$, and leukemia $[161,162]$. The first nanoformulation of resveratrol was developed with the help of chitosan. The chitosan nanoformulations have a sustained release profile through in vitro studies. A decrease in release rate was observed with an addition of solidification agent [163]. In another study, the results expressed that 12-h prematuration of resveratrol-loaded NPs defended cells from beta-amyloid peptide-induced loss in a dosedependent manner by attenuating intracellular oxidative stress and caspase- 3 activity [164]. Resveratrol-loaded NPs at low dose resulted in higher cell death when compared to the free resveratrol at same dose. These kinds of results were not observed to be revoked by the inclusion of vitamin E. The study reported viability of methoxy PEG-poly (caprolactone)-based resveratrol NPs with high entrapment efficiency. The difference in cytotoxicity between resveratrol-loaded NPs and pure resveratrol could be due to the low level of intracellular ROS [165].

The bovine serum albumin (BSA) NPs containing resveratrol having antitumor activity were studied by Guo et al. [166]. The administered resveratrol-BSA NPs significantly inhibited the growth rate of subcutaneously implanted human primary ovarian cancer cells $\operatorname{SKOV}(3)$ after 3 weeks in nude mice compared to free resveratrol.

\section{Taxol}

Taxol, an effective anticancer agent, has stimulated an intense research effort. Taxol is effective against leukemia and various solid tumors in the breast, ovary, brain, and lungs [140, 167-170]. It was first isolated in 1971 from the bark of Pacific Yew tree, and is among the first FDA-approved chemotherapy drugs obtained from natural sources. Paclitaxel was developed by Bristol-Myers Squibb and sold as Taxol ${ }^{\mathrm{TM}}$. Paclitaxel PLGA-loaded NPs were synthesized using interfacial deposition method. Biphasic release of paclitaxel was characterized by fast release during the first $24 \mathrm{~h}$ of dissolution studies, followed by sustained release. The results suggested that cytotoxic effect of paclitaxel NPs was more as compared to Taxol [171]. Paclitaxel PLGA NPs prepared by a modified solvent extraction technique showed that the natural emulsifiers are better for paclitaxel NP formulation over the conventional macromolecular emulsifiers like polyvinyl alcohol. After 24-h incubation of HT-29 cancer cell line, the cell mortality caused by paclitaxel NPs was 13 times than free paclitaxel [172]. The antiproliferative activity of nanoparticulate paclitaxel in a human prostate cancer cell line and its effect on tumor inhibition in a murine model of prostate cancer has been reported. The NPs released $60 \%$ paclitaxel in 60 days. The $\mathrm{IC}_{50}$ of the drug with unconjugated NPs was fivefold higher than the transferrin-conjugated NPs [173].

\section{Camptothecin (CPT)}

It is a cytotoxic alkaloid obtained from Camptotheca acuminate first reported by Wall and Wani in 1966. CPT and its derivatives target the nuclear enzyme topoisomerase I and inhibit religation of cleaved, single-stranded DNA. This inhibits the process of replication and cell death. CPT and its derivatives exhibit excellent anticancer 
activity. Extreme lipophilicity and instability of the lactone ring is the major limitation of CPT [140]. Hycamtin (topotecan) and camptosar are FDA-approved water-soluble derivatives of CPT, which are used to treat ovarian cancer and advanced colorectal carcinoma, respectively [174]. Significant tumor inhibition effect of irinotecan NPs $(20 \mathrm{mg} / \mathrm{kg})$ in mouse models with subcutaneous sarcoma 180 has been reported. Higher concentration of the drug was maintained for a longer residence time and had better tumor suppression effect [175]. The in vitro studies of CPT-PLGA NPs coated with antibodies against colorectal cancer were carried out by McCarron et al. Fluorescently labeled NPs cleared the high uptake of the antibody NPs compared to the NPs without the antibody [176].

Min and co-workers synthesized hydrophobically modified glycol chitosan (HGC) NPs encapsulating CPT. The size of HGC-CPT nanaoparticles was around 280-330 $\mathrm{nm}$ and had $80 \%$ loading efficiency. The anticancer activity of HGC-CPT NP was observed in mice having subcutaneously implanted MDA-MB231 xenograft. The intravenous injection of the nanoformulation seemed to suppress tumor growth when compared to the free dose. In vivo studies of the dye-labeled NPs cleared that large amount of NPs was accumulated in tumor spot. Approximately, increase of the therapeutic effect of CPT when loaded in NPs might be because of the higher accumulation of CPT at the tumor site [177].

\section{Curcumin}

Curcumin, obtained from Curcuma longa, is used for the treatment of various cancers including multiple myeloma, pancreatic, myelodysplastic syndromes, colon, and psoriasis. It inhibits cell proliferation and promotes apoptosis [140]. Low solubility, bioavailability, and stability are the major limitations of curcumin. It is unstable in the gut [178], and a small amount of curcumin that passes through the GI tract is degraded rapidly. Application of nanotechnology has solved these reported limitations of curcumin in a very effective way. Bisht et al. [179] reported cross-linked and random copolymers of $\mathrm{N}$ isopropylacrylamide, with $\mathrm{N}$-vinyl-2-pyrrolidone and PEG monoacrylate NPs, loaded with curcumin. The size range of these NPs was within $50 \mathrm{~nm}$. Sahu and coworkers synthesized polymeric amphiphile with the help of methoxy PEG and palmitic acid as the hydrophilic and hydrophobic segment, respectively. The conjugate step carried out in a single-step reaction showed minimal toxicity on HeLa cells [180]. Thangapazham and coworkers explained merits of nanoformulated curcumin over the free curcumin. They stimulate the targeted delivery of curcumin for prostate cancer using curcumin-loaded liposomes coated with prostate-specific membrane antigen antibodies [181]. The antiproliferative activity of liposomal curcumin was studied using LNCaP and C4-2B human prostate cancer cell lines. The results showed $75 \%-85 \%$ decrease in the cellular proliferation. Curcumin has been encapsulated in nanosized carriers using chitosan, alginate, and pluronic. The product was synthesized by ionotropic pre-gelation method followed by polycationic cross-linking. In this process, pluronic F127 enhanced the solubility of curcumin. The NPs were successful in cellular internalization of curcumin [182]. Curcumin-loaded poly (caprolactone) nanofiber matrix has potential as a wound dressing with reduced inflammation and an increased wound closure rate [183]. PEGylated curcumin conjugates are more effective in pancreatic cancer cell growth inhibition than free curcumin [184]. In a study, Shaikh et al. reported diffusion-controlled in vitro release profile of curcumin followed Higuchi's release pattern. The pharmacokinetics revealed that curcumin-entrapped NPs demonstrate ninefold higher oral bioavailability when compared to curcumin administered with piperine as an absorption enhancer [185].

\section{Patents Based on Nanoformulations}

Development of effective and safe nanoformulation is still challenging. The developed formulation should be safe for the biological environment. During the past 2-3 decades, considerable attention has been made to provide improved therapeutic benefits of drugs using nanotechnology. The interest of formulation scientists in the development of nanomedicines for the treatment and diagnosis is clearly reflected from the increasing number of issued patents. The patented nanoformulations are based on overall knowledge of the synthetic approach and good expertise in physical and chemical properties. There are some patented products discussed in this study based on nanodevelopments, which bring a wave in the drug-delivery field with less expense on developed product and also have excellent response paving the way to the researchers to fill the drug piperine with innovative developments (Table V). Recently, Bhatia et al. [206] published an interesting article reporting regulatory implications and current status of nanomedicine in India.

\section{Conclusions}

The present review recapitulates various nanoformulations used in drug delivery, their toxicological effects, and significance of nanotechnology in delivering natural bioactives. However, there is an essential need to develop rapid whole animal-based testing methods to assess the potential toxicity of nanomaterials in biomedical science. Mathematical modeling might be promising tool for technological revolution of nanotechnology in biomedicine. 
Maurya et al.

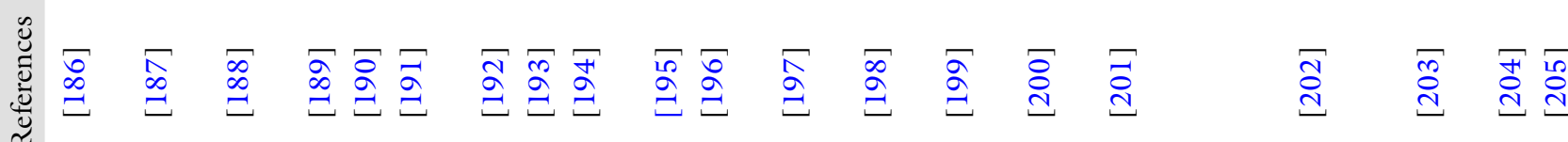

:

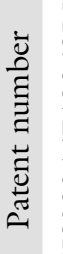

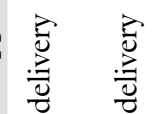

हy

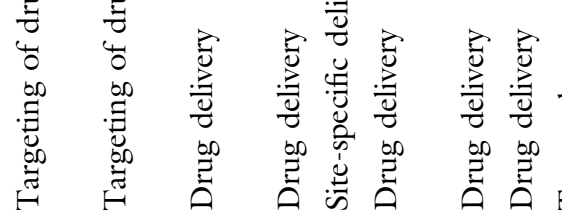

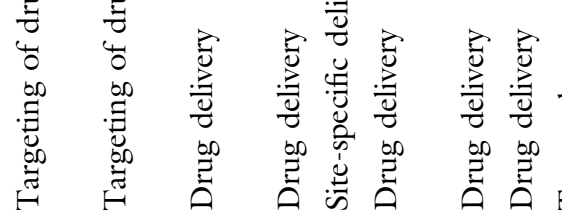

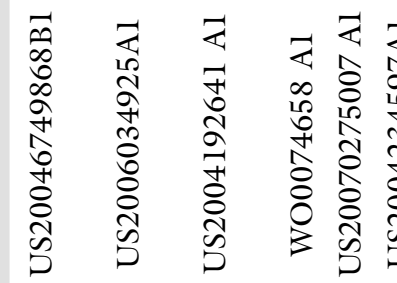

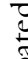

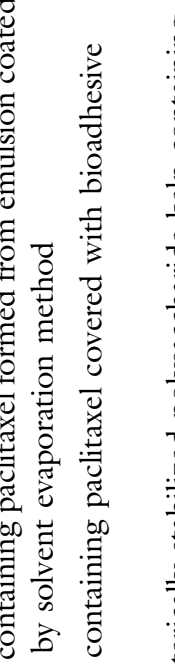

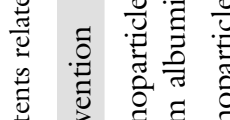

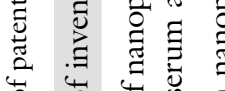

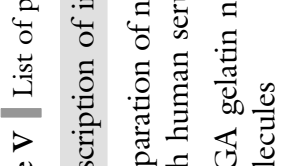

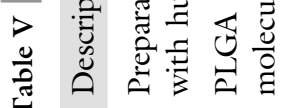

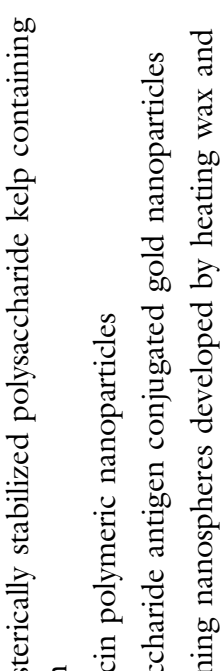

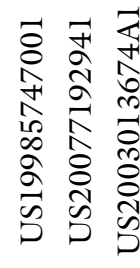

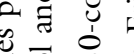

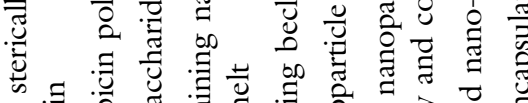

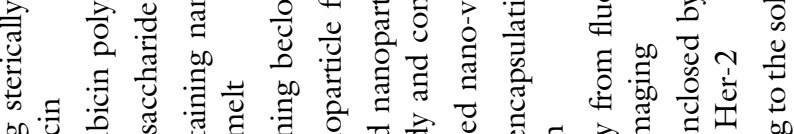

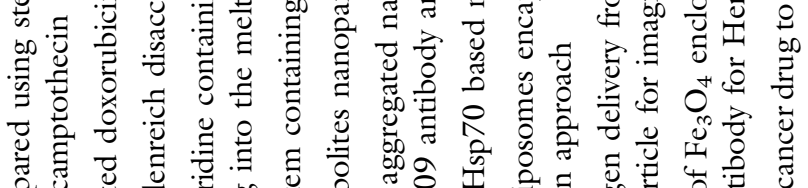

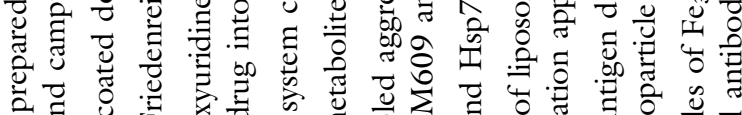

产愛

节节

氙语

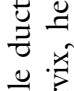

:

空.

苛

㟧高

苟

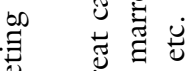

品

요요

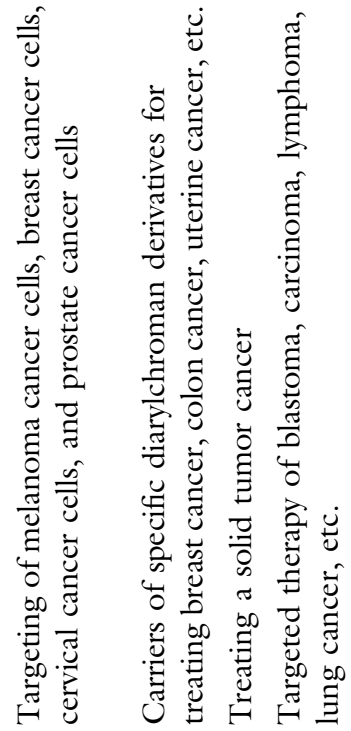

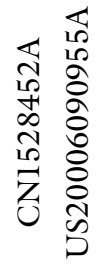

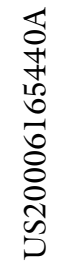

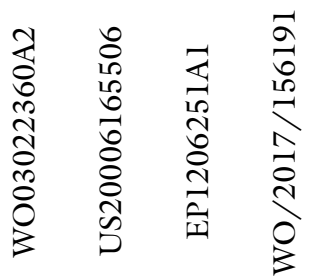

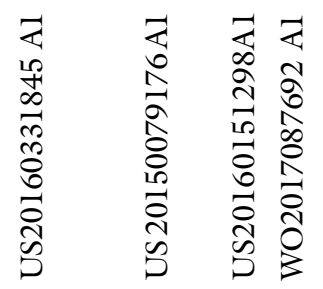

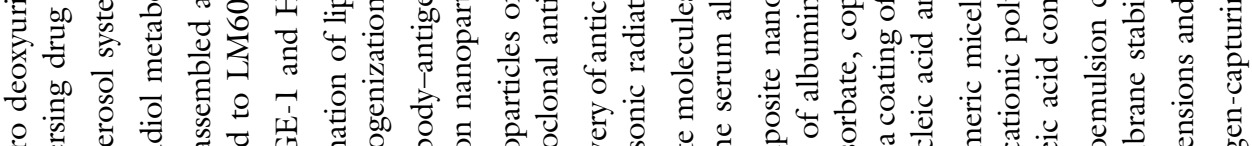

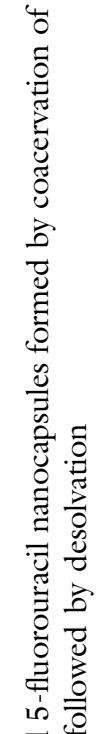

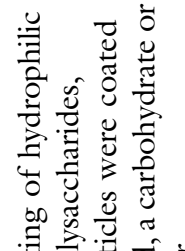

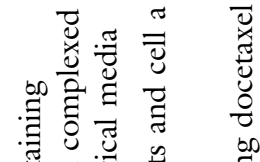

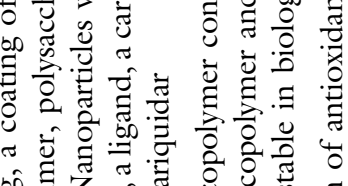

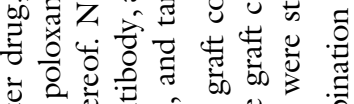

पू山

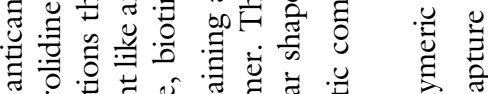

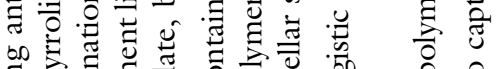

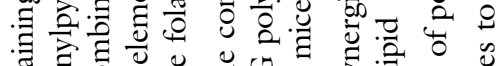

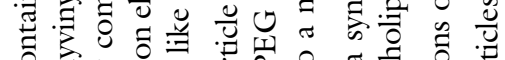

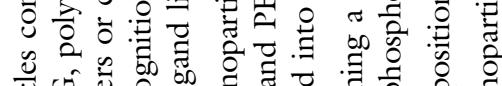

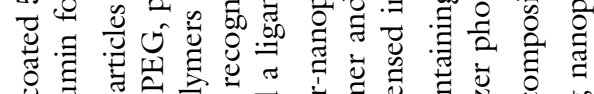

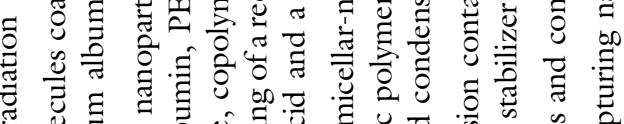

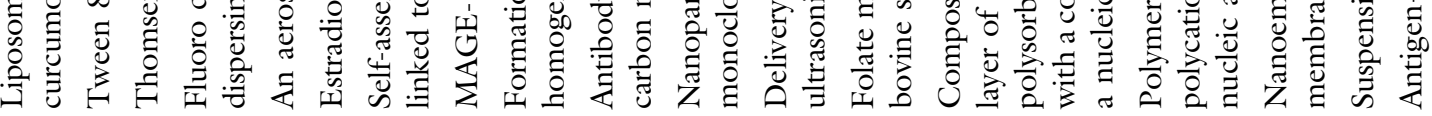


Overall, nanotechnology is a new path in the development of effective carrier systems for site-specific delivery of bioactives. This will introduce new vistas in clinically considering their various merits like maximum efficacy, targeted effects, and improved patient compliance.

$$
* * *
$$

Funding sources: No financial support was received for this study.

Authors' contribution: The literature data were collected by AM, AKS, GM, and RA. The data presentation was performed in collaboration with all authors. All authors participated in the interpretation of data, preparation, and editing of manuscript for intellectual content. They have also approved the final version of the manuscript.

Conflict of interest: The authors confirm that this article content has no conflict of interest.

\section{References}

1. Awasthi R, Pant I, Kulkarni GT, Satiko Kikuchi I, de Jesus Andreoli Pinto T, Dua K, Ramana Malipeddi V: Opportunities and challenges in nano-structure mediated drug delivery: Where do we stand? Curr Nanomed 6, 78-104 (2016)

2. Chen MC, Sonaje K, Chen KJ, Sung HW: A review of the prospects for polymeric nanoparticle platforms in oral insulin delivery. Biomaterials 32, 9826-9838 (2011)

3. Khalil NM, do Nascimento TC, Casa DM, Dalmolin LF, de Mattos AC, Hoss I, Romano MA, Mainardes RM: Pharmacokinetics of curcumin-loaded PLGA and PLGA-PEG blend nanoparticles after oral administration in rats. Colloids Surf B Biointerfaces 101, 353-360 (2013)

4. Narvekar M, Xue HY, Eoh JY, Wong HL: Nanocarrier for poorly water-soluble anticancer drugs - Barriers of translation and solutions. AAPS PharmSciTech 15, 822-833 (2014)

5. Zhao L, Feng SS: Enhanced oral bioavailability of paclitaxel formulated in vitamin E-TPGS emulsified nanoparticles of biodegradable polymers: In vitro and in vivo studies. J Pharm Sci 99, 3552-3560 (2010)

6. Patel T, Zhou J, Piepmeier JM, Saltzman WM: Polymeric nanoparticles for drug delivery to the central nervous system. Adv Drug Deliv Rev 64, 701-705 (2012)

7. Roger E, Kalscheuer S, Kirtane A, Guru BR, Grill AE, WhittumHudson J, Panyam J: Folic acid functionalized nanoparticles for enhanced oral drug delivery. Mol Pharm 9, 2103-2110 (2012)

8. Luo CF, Yuan M, Chen MS, Liu SM, Zhu L, Huang BY, Liu XW, Xiong $\mathrm{W}$ : Pharmacokinetics, tissue distribution and relative bioavailability of puerarin solid lipid nanoparticles following oral administration. Int J Pharm 410, 138-144 (2011)

9. El-Sherbiny IM, Abdel-Mogib M, Dawidar AA, Elsayed A, Smyth HD: Biodegradable $\mathrm{pH}$-responsive alginate-poly (lactic-coglycolic acid) nano/micro hydrogel matrices for oral delivery of silymarin. Carbohydr Polym 83, 1345-1354 (2011)

10. Kim S, Kim JY, Huh KM, Acharya G, Park K: Hydrotropic polymer micelles containing acrylic acid moieties for oral delivery of paclitaxel. J Control Release 132, 222-229 (2008)

11. Lee SC, Huh KM, Lee J, Cho YW, Galinsky RE, Park K: Hydrotropic polymeric micelles for enhanced paclitaxel solubility: In vitro and in vivo characterization. Biomacromolecules 8, 202-208 (2007)

12. Parmentier J, Thewes B, Gropp F, Fricker G: Oral peptide delivery by tetraether lipid liposomes. Int $\mathrm{J}$ Pharm 415, $150-157$ (2011)
13. Niu M, Lu Y, Hovgaard L, Guan P, Tan Y, Lian R, Qi J, Wu W: Hypoglycemic activity and oral bioavailability of insulin-loaded liposomes containing bile salts in rats: The effect of cholate type, particle size and administered dose. Eur J Pharm Biopharm 81, 265-272 (2012)

14. Kohli K, Chopra S, Dhar D, Arora S, Khar RK: Self-emulsifying drug delivery systems: An approach to enhance oral bioavailability. Drug Discov Today 15, 958-965 (2010)

15. Zhang L, Zhu W, Yang C, Guo H, Yu A, Ji J, Gao Y, Sun M, Zhai G: A novel folate-modified self-microemulsifying drug delivery system of curcumin for colon targeting. Int J Nanomedicine 7, 151 (2012)

16. Piao H, Ouyang M, Xia D, Quan P, Xiao W, Song Y, Cui F: In vitro-in vivo study of $\mathrm{CoQ} 10$-loaded lipid nanoparticles in comparison with nanocrystals. Int J Pharm 419, 255-259 (2011)

17. Liu Y, Wang P, Sun C, Zhao J, Du Y, Shi F, Feng N: Bioadhesion and enhanced bioavailability by wheat germ agglutinin-grafted lipid nanoparticles for oral delivery of poorly water-soluble drug bufalin. Int J Pharm 419, 260-265 (2011)

18. Wang XQ, Dai JD, Zhang H, Zhang X, Wang JC, Zhang Q: Absorption mechanism of cyclosporine A loaded $\mathrm{pH}$-sensitive nanoparticles in rats. J Nanosci Nanotechnol 8, 2422-2431 (2008)

19. Hsieh WH, Chang SF, Chen HM, Chen JH, Liaw J: Oral gene delivery with cyclo-(D-Trp-Tyr) peptide nanotubes. Mol Pharm 9, 1231-1249 (2012)

20. Kumar A, Chen F, Mozhi A, Zhang X, Zhao Y, Xue X, Hao Y, Zhang X, Wang PC, Liang XJ: Innovative pharmaceutical development based on unique properties of nanoscale delivery formulation. Nanoscale 5, 8307-8325 (2013)

21. Pillai G: Nanomedicines for cancer therapy: An update of FDA approved and those under various stages of development. SOJ Pharm Pharm Sci 1, 13 (2014)

22. Xie H, Smith JW: Fabrication of PLGA nanoparticles with a fluidic nanoprecipitation system. J Nanobiotechnol 8, 18 (2010)

23. Xie X, Tao Q, Zou Y, Zhang F, Guo M, Wang Y, Wang H, Zhou Q, Yu S: PLGA nanoparticles improve the oral bioavailability of curcumin in rats: Characterizations and mechanisms. J Agric Food Chem 59, 9280-9289 (2011)

24. Italia JL, Bhatt DK, Bhardwaj V, Tikoo K, Kumar MR: PLGA nanoparticles for oral delivery of cyclosporine: Nephrotoxicity and pharmacokinetic studies in comparison to Sandimmune Neoral ${ }^{\circledR}$. J Control Release 119, 197-206 (2007)

25. Singh AK, Sharma AK, Khan I, Gothwal A, Gupta L, Gupta U (2017): Oral drug delivery potential of dendrimers. In: Nanostructures for Oral Medicine, eds Andronescu E, Grumezescu AM, Elsevier, New York, pp. 231-261

26. Chakraborty S, Shukla D, Vuddanda PR, Mishra B, Singh S: Utilization of adsorption technique in the development of oral delivery system of lipid based nanoparticles. Colloids Surf B Biointerfaces 81, 563-569 (2010)

27. Sarmento B, Martins S, Ferreira D, Souto EB: Oral insulin delivery by means of solid lipid nanoparticles. Int J Nanomedicine 2, 743 (2007)

28. Silva AC, Kumar A, Wild W, Ferreira D, Santos D, Forbes B: Long-term stability, biocompatibility and oral delivery potential of risperidone-loaded solid lipid nanoparticles. Int J Pharm 436, 798-805 (2012)

29. Luo CF, Hou N, Tian J, Yuan M, Liu SM, Xiong LG, Luo JD, Chen MS: Metabolic profile of puerarin in rats after intragastric administration of puerarin solid lipid nanoparticles. Int J Nanomedicine 8, 933 (2013)

30. Bardajee GR, Pourjavadi A, Soleyman R: Novel nano-porous hydrogel as a carrier matrix for oral delivery of tetracycline hydrochloride. Colloids Surf A Physicochem Eng Aspects 392, 16-24 (2011)

31. Kim Y, Thapa M, Hua DH, Chang KO: Biodegradable nanogels for oral delivery of interferon for norovirus infection. Antiviral Res $89,165-173(2011)$ 
32. Kurnia JC, Birgersson E, Mujumdar AS: Analysis of a model for pH-sensitive hydrogels. Polymer 53, 613-622 (2012)

33. Murdan S: Electro-responsive drug delivery from hydrogels. J Control Release 92, 1-7 (2003)

34. Wenceslau AC, dos Santos FG, Ramos ÉR, Nakamura CV, Rubira AF, Muniz EC: Thermo-and pH-sensitive IPN hydrogels based on PNIPAAm and PVA-Ma networks with LCST tailored close to human body temperature. Mater Sci Eng C 32, 1259-1265 (2012)

35. Zhang J, Xie R, Zhang SB, Cheng CJ, Ju XJ, Chu LY: Rapid pH/ temperature-responsive cationic hydrogels with dual stimulisensitive grafted side chains. Polymer 50, 2516-2525 (2009)

36. Cartiera MS, Ferreira EC, Caputo C, Egan ME, Caplan MJ, Saltzman WM: Partial correction of cystic fibrosis defects with PLGA nanoparticles encapsulating curcumin. Mol Pharm 7, 86-93 (2009)

37. Coimbra M, Rijcken CJ, Stigter M, Hennink WE, Storm G, Schiffelers RM: Antitumor efficacy of dexamethasone-loaded core-crosslinked polymeric micelles. J Control Release 163 , 361-367 (2012)

38. Huang X, Xiao Y, Lang M: Micelles/sodium-alginate composite gel beads: A new matrix for oral drug delivery of indomethacin. Carbohydr Polym 87, 790-798 (2012)

39. Gaucher G, Satturwar P, Jones MC, Furtos A, Leroux JC: Polymeric micelles for oral drug delivery. Eur J Pharm Biopharm $76,147-158(2010)$

40. Peltier S, Oger JM, Lagarce F, Couet W, Benoit JP: Enhanced oral paclitaxel bioavailability after administration of paclitaxel-loaded lipid nanocapsules. Pharm Res 23, 1243-1250 (2006)

41. Sudimack JJ, Guo W, Tjarks W, Lee RJ: A novel pH-sensitive liposome formulation containing oleyl alcohol. Biochim Biophys Acta $1564,31-37$ (2002)

42. Law SL, Huang KJ, Chiang CH: Acyclovir-containing liposomes for potential ocular delivery: Corneal penetration and absorption. J Control Release 63, 135-140 (2000)

43. Li P, Nielsen HM, Müllertz A: Oral delivery of peptides and proteins using lipid-based drug delivery systems. Expert Opin Drug Deliv 9, 1289-1304 (2012)

44. Takeuchi H, Matsui Y, Sugihara H, Yamamoto H, Kawashima Y: Effectiveness of submicron-sized, chitosan-coated liposomes in oral administration of peptide drugs. Int J Pharm 303, 160-170 (2005)

45. Hong JY, Kim JK, Song YK, Park JS, Kim CK: A new selfemulsifying formulation of itraconazole with improved dissolution and oral absorption. J Control Release 110, 332-338 (2006)

46. Date AA, Desai N, Dixit R, Nagarsenker M: Self-nanoemulsifying drug delivery systems: Formulation insights, applications and advances. Nanomedicine 5, 1595-1616 (2010)

47. Gutiérrez JM, González C, Maestro A, Solè IM, Pey CM, Nolla J: Nano-emulsions: New applications and optimization of their preparation. Curr Opin Colloid Interface Sci 13, 245-251 (2008)

48. Rao SV, Shao J: Self-nanoemulsifying drug delivery systems (SNEDDS) for oral delivery of protein drugs: I. Formulation development. Int J Pharm 362, 2-9 (2008)

49. Parveen R, Baboota S, Ali J, Ahuja A, Vasudev SS, Ahmad S: Oil based nanocarrier for improved oral delivery of silymarin: In vitro and in vivo studies. Int J Pharm 413, 245-253 (2011)

50. Bali V, Ali M, Ali J: Study of surfactant combinations and development of a novel nanoemulsion for minimising variations in bioavailability of ezetimibe. Colloids Surf B Biointerfaces $76,410-420(2010)$

51. Liu Y, Zhang P, Feng N, Zhang X, Wu S, Zhao J: Optimization and in situ intestinal absorption of self-microemulsifying drug delivery system of oridonin. Int J Pharm 365, 136-142 (2009)

52. Cui J, Yu B, Zhao Y, Zhu W, Li H, Lou H, Zhai G: Enhancement of oral absorption of curcumin by self-microemulsifying drug delivery systems. Int J Pharm 371, 148-155 (2009)
53. Shen Q, Li X, Yuan D, Jia W: Enhanced oral bioavailability of daidzein by self-microemulsifying drug delivery system. Chem Pharm Bull 58, 639-643 (2010)

54. Gursoy RN, Benita S: Self-emulsifying drug delivery systems (SEDDS) for improved oral delivery of lipophilic drugs. Biomed Pharmacother 58, 173-182 (2004)

55. Wang L, Dong J, Chen J, Eastoe J, Li X: Design and optimization of a new self-nanoemulsifying drug delivery system. J Colloid Interface Sci 330, 443-448 (2009)

56. Date AA, Nagarsenker MS: Design and evaluation of selfnanoemulsifying drug delivery systems (SNEDDS) for cefpodoxime proxetil. Int J Pharm 329, 166-172 (2007)

57. Beg S, Sandhu PS, Batra RS, Khurana RK, Singh B: QbDbased systematic development of novel optimized solid selfnanoemulsifying drug delivery systems (SNEDDS) of lovastatin with enhanced biopharmaceutical performance. Drug Deliv 22, 765-784 (2015)

58. Nepal PR, Han HK, Choi HK: Preparation and in vitro-in vivo evaluation of Witepsol ${ }^{\circledR} \mathrm{H} 35$ based self-nanoemulsifying drug delivery systems (SNEDDS) of coenzyme $\mathrm{Q}_{10}$. Eur J Pharm Sci 39, 224-232 (2010)

59. Villar AM, Naveros BC, Campmany AC, Trenchs MA, Rocabert $\mathrm{CB}$, Bellowa LH: Design and optimization of self-nanoemulsifying drug delivery systems (SNEDDS) for enhanced dissolution of gemfibrozil. Int J Pharm 431, 161-175 (2012)

60. Zhao L, Zhang L, Meng L, Wang J, Zhai G: Design and evaluation of a self-microemulsifying drug delivery system for apigenin. Drug Dev Ind Pharm 39, 662-669 (2013)

61. Zhao Y, Wang C, Chow AH, Ren K, Gong T, Zhang Z, Zheng Y: Self-nanoemulsifying drug delivery system (SNEDDS) for oral delivery of Zedoary essential oil: Formulation and bioavailability studies. Int J Pharm 383, 170-177 (2010)

62. Elnaggar YS, El-Massik MA, Abdallah OY: Self-nanoemulsifying drug delivery systems of tamoxifen citrate: Design and optimization. Int J Pharm 380, 133-141 (2009)

63. Mauludin R, Müller RH, Keck CM: Development of an oral rutin nanocrystal formulation. Int J Pharm 370, 202-209 (2009)

64. Kesisoglou F, Panmai S, Wu Y: Nanosizing - Oral formulation development and biopharmaceutical evaluation. Adv Drug Deliv Rev 59, 631-644 (2007)

65. Junghanns JU, Muller RH: Nanocrystal technology, drug delivery and clinical applications. Int J Nanomedicine 3, 295 (2008)

66. Merisko-Liversidge E, Liversidge GG, Cooper ER: Nanosizing: A formulation approach for poorly-water-soluble compounds. Eur J Pharm Sci 18, 113-120 (2003)

67. Svenson S, Tomalia DA: Dendrimers in biomedical applications Reflections on the field. Adv Drug Deliv Rev 64, 102-115 (2012)

68. D'emanuele A, Jevprasesphant R, Penny J, Attwood D: The use of a dendrimer-propranolol prodrug to bypass efflux transporters and enhance oral bioavailability. J Control Release 95, 447-453 (2004)

69. Kateb B, Chiu K, Black KL, Yamamoto V, Khalsa B, Ljubimova JY, Ding H, Patil R, Portilla-Arias JA, Modo M, Moore DF: Nanoplatforms for constructing new approaches to cancer treatment, imaging, and drug delivery: What should be the policy? Neuroimage 54, S106-S124 (2011)

70. Sadekar S, Ghandehari H: Transepithelial transport and toxicity of PAMAM dendrimers: Implications for oral drug delivery. Adv Drug Deliv Rev 64, 571-588 (2012)

71. Mukherjee SP, Byrne HJ: Polyamidoamine dendrimer nanoparticle cytotoxicity, oxidative stress, caspase activation and inflammatory response: Experimental observation and numerical simulation. Nanomedicine 9, 202-211 (2013)

72. Ke W, Zhao Y, Huang R, Jiang C, Pei Y: Enhanced oral bioavailability of doxorubicin in a dendrimer drug delivery system. J Pharm Sci 97, 2208-2216 (2008) 
73. Kaminskas LM, Boyd BJ, Porter CJ: Dendrimer pharmacokinetics: The effect of size, structure and surface characteristics on ADME properties. Nanomedicine 6, 1063-1084 (2011)

74. Zhang Y, Wei W, Lv P, Wang L, Ma G: Preparation and evaluation of alginate-chitosan microspheres for oral delivery of insulin. Eur J Pharm Biopharm 77, 11-19 (2011)

75. Hardman R: A toxicologic review of quantum dots: Toxicity depends on physicochemical and environmental factors. Environ Health Perspect 114, 165 (2006)

76. De Jong WH, Borm PJ: Drug delivery and nanoparticles: Applications and hazards. Int $\mathrm{J}$ Nanomedicine 3, 133-147 (2008)

77. Buxton DB, Lee SC, Wickline SA, Ferrari M: Recommendations of the national heart, lung, and blood institute nanotechnology working group. Circulation 108, 2737-2742 (2003)

78. Ray PC, Yu H, Fu PP: Toxicity and environmental risks of nanomaterials: Challenges and future needs. J Environ Sci Health C 27, 1-35 (2009)

79. Latha PP, Kumari RS: Toxicity and environmental risks of nanomaterials: Challenges and future needs. Indian J Res Pharm Biotechnol 4, 247 (2016)

80. Bahadar H, Maqbool F, Niaz K, Abdollahi M: Toxicity of nanoparticles and an overview of current experimental models. Iran Biomed J 20, l (2016)

81. Borm PJ, Schins RP, Albrecht C: Inhaled particles and lung cancer, part B: Paradigms and risk assessment. Int J Cancer $110,3-14(2004)$

82. Pope CA, Burnett RT, Thurston GD, Thun MJ, Calle EE, Krewski D, Godleski JJ: Cardiovascular mortality and long-term exposure to particulate air pollution. Circulation 109, 71-77 (2004)

83. Comparetti EJ, Pedrosa VD, Kaneno R: Carbon nanotube as a tool for fighting cancer. Bioconjugate Chem 29, 709-718 (2017)

84. Shi H, Magaye R, Castranova V, Zhao J: Titanium dioxide nanoparticles: A review of current toxicological data. Part Fibre Toxicol 10, 15 (2013)

85. Fadeel B, Garcia-Bennett AE: Better safe than sorry: Understanding the toxicological properties of inorganic nanoparticles manufactured for biomedical applications. Adv Drug Deliv Rev 62, 362-374 (2010)

86. Brook RD, Franklin B, Cascio W, Hong Y, Howard G, Lipsett M, Luepker R, Mittleman M, Samet J, Smith SC, Tager I: Air pollution and cardiovascular disease: A statement for healthcare professionals from the Expert Panel on Population and Prevention Science of the American Heart Association. Circulation 109, 2655-2671 (2004)

87. Dreher KL: Health and environmental impact of nanotechnology: Toxicological assessment of manufactured nanoparticles. Toxicol Sci 77, 3-5 (2004)

88. Holsapple MP, Farland WH, Landry TD, Monteiro-Riviere NA, Carter JM, Walker NJ, Thomas KV: Research strategies for safety evaluation of nanomaterials, part II: Toxicological and safety evaluation of nanomaterials, current challenges and data needs. Toxicol Sci 88, 12-17 (2005)

89. Dockery DW, Pope CA, Xu X, Spengler JD, Ware JH, Fay ME, Ferris BG Jr, Speizer FE: An association between air pollution and mortality in six US cities. NEJM 329, 1753-1759 (1993)

90. Shvedova A, Castranova V, Kisin E, Schwegler-Berry D, Murray A, Gandelsman V, Maynard A, Baron P: Exposure to carbon nanotube material: Assessment of nanotube cytotoxicity using human keratinocyte cells. J Toxicol Environ Health 66, 1909-1926 (2003)

91. Sayes CM, Liang F, Hudson JL, Mendez J, Guo W, Beach JM, Moore VC, Doyle CD, West JL, Billups WE, Ausman KD: Functionalization density dependence of single-walled carbon nanotubes cytotoxicity in vitro. Toxicol Lett 161, 135-142 (2006)
92. Radomski A, Jurasz P, Alonso-Escolano D, Drews M, Morandi M, Malinski T, Radomski MW: Nanoparticle-induced platelet aggregation and vascular thrombosis. Br J Pharmacol 146, 882-893 (2005)

93. Monteiro-Riviere NA, Nemanich RJ, Inman AO, Wang YY, Riviere JE: Multi-walled carbon nanotube interactions with human epidermal keratinocytes. Toxicol Lett 155, 377-384 (2005)

94. Warheit DB, Laurence BR, Reed KL, Roach DH, Reynolds GA, Webb TR: Comparative pulmonary toxicity assessment of single-wall carbon nanotubes in rats. Toxicol Sci 77, 117-125 (2004)

95. Muller J, Huaux F, Moreau N, Misson P, Heilier JF, Delos M, Arras M, Fonseca A, Nagy JB, Lison D: Respiratory toxicity of multi-wall carbon nanotubes. Toxicol Appl Pharmacol 207, 221-231 (2005)

96. Lam CW, James JT, McCluskey R, Hunter RL: Pulmonary toxicity of single-wall carbon nanotubes in mice 7 and 90 days after intratracheal instillation. Toxicol Sci 77, 126-134 (2004)

97. Kroto HW, Heath JR, O'Brien SC, Curl RF, Smalley RE: C60: Buckminsterfullerene. Nature 318, 162-163 (1985)

98. Partha R, Conyers JL: Biomedical applications of functionalized fullerene-based nanomaterials. Int J Nanomedicine 4, 261 (2009)

99. Kolosnjaj J, Szwarc H, Moussa F (2007): Toxicity studies of fullerenes and derivatives. In: Bio-Applications of Nanoparticles, ed Chan WCW, Springer, New York, pp. 168-180

100. Zhu S, Oberdörster E, Haasch ML: Toxicity of an engineered nanoparticle (fullerene, C 60) in two aquatic species, Daphnia and fathead minnow. Mar Environ Res 62, S5-S9 (2006)

101. Lovern SB, Klaper R: Daphnia magna mortality when exposed to titanium dioxide and fullerene (C60) nanoparticles. Environ Toxicol Chem 25, 1132-1137 (2006)

102. Oberdorster G, Sharp Z, Atudorei V, Elder A, Gelein R, Kreyling W, Cox C: Translocation of inhaled ultrafine particles to the brain. Inhal Toxicol 16, 437-445 (2004)

103. Jain K, Kesharwani P, Gupta U, Jain NK: Dendrimer toxicity: Let's meet the challenge. Int J Pharm 394, 122-142 (2010)

104. Asthana A, Chauhan AS, Diwan PV, Jain NK: Poly (amidoamine) (PAMAM) dendritic nanostructures for controlled site specific delivery of acidic anti-inflammatory active ingredient. AAPS PharmSciTech 6, E536-E542 (2005)

105. Chen HT, Neerman MF, Parrish AR, Simanek EE: Cytotoxicity, hemolysis, and acute in vivo toxicity of dendrimers based on melamine, candidate vehicles for drug delivery. J Am Chem Soc 126, 10044-10048 (2004)

106. Jevprasesphant R, Penny J, Jalal R, Attwood D, McKeown NB, D'emanuele A: The influence of surface modification on the cytotoxicity of PAMAM dendrimers. Int J Pharm 252, 263-266 (2003)

107. Malik N, Wiwattanapatapee R, Klopsch R, Lorenz K, Frey H, Weener JW, Meijer EW, Paulus W, Duncan R: Dendrimers: Relationship between structure and biocompatibility in vitro, and preliminary studies on the biodistribution of 125I-labelled polyamidoamine dendrimers in vivo. J Control Release 65, 133-148 (2000)

108. Fischer D, Li Y, Ahlemeyer B, Krieglstein J, Kissel T: In vitro cytotoxicity testing of polycations: Influence of polymer structure on cell viability and hemolysis. Biomaterials 24, 1121-1131 (2003)

109. Mecke A, Uppuluri S, Sassanella TM, Lee DK, Ramamoorthy A, Baker JR, Orr BG, Holl MM: Direct observation of lipid bilayer disruption by poly (amidoamine) dendrimers. Chem Phys Lipids 132, 3-14 (2004)

110. Leroueil PR, Berry SA, Duthie K, Han G, Rotello VM, McNerny DQ, Baker JR, Orr BG, Banaszak Holl MM: Wide varieties of cationic nanoparticles induce defects in supported lipid bilayers. Nano Lett 8, 420-424 (2008) 
111. Zhang ZY, Smith BD: High-generation polycationic dendrimers are unusually effective at disrupting anionic vesicles: Membrane bending model. Bioconjugate Chem 11, 805-814 (2000)

112. Manunta M, Nichols BJ, Tan PH, Sagoo P, Harper J, George AJ: Gene delivery by dendrimers operates via different pathways in different cells, but is enhanced by the presence of caveolin. J Immunol Methods 314, 134-146 (2006)

113. Hong S, Bielinska AU, Mecke A, Keszler B, Beals JL, Shi X, Balogh L, Orr BG, Baker JR Jr, Banaszak Holl MM: Interaction of poly (amidoamine) dendrimers with supported lipid bilayers and cells: Hole formation and the relation to transport. Bioconjugate Chem 15, 774-782 (2004)

114. Hoshino A, Fujioka K, Oku T, Suga M, Sasaki YF, Ohta T, Yasuhara M, Suzuki K, Yamamoto K: Physicochemical properties and cellular toxicity of nanocrystal quantum dots depend on their surface modification. Nano Lett 4, 2163-2169 (2004)

115. Shiohara A, Hoshino A, Hanaki KI, Suzuki K, Yamamoto K: On the cytotoxicity caused by quantum dots. Microbiol Immunol $48,669-675$ (2004)

116. Lovrić J, Bazzi HS, Cuie Y, Fortin GR, Winnik FM, Maysinger D: Differences in subcellular distribution and toxicity of green and red emitting CdTe quantum dots. Int J Mol Med 83, 377-385 (2005)

117. Hoshino A, Manabe N, Fujioka K, Suzuki K, Yasuhara M, Yamamoto K: Use of fluorescent quantum dot bioconjugates for cellular imaging of immune cells, cell organelle labeling, and nanomedicine: Surface modification regulates biological function, including cytotoxicity. J Artif Organs 10, 149-157 (2007)

118. Choi AO, Cho SJ, Desbarats J, Lovrić J, Maysinger D: Quantum dot-induced cell death involves Fas upregulation and lipid peroxidation in human neuroblastoma cells. J Nanobiotechnol $5,1(2007)$

119. Lovrić J, Cho SJ, Winnik FM, Maysinger D: Unmodified cadmium telluride quantum dots induce reactive oxygen species formation leading to multiple organelle damage and cell death. Chem Biol 12, 1227-1234 (2005)

120. Derfus AM, Chan WC, Bhatia SN: Probing the cytotoxicity of semiconductor quantum dots. Nano lett 4, 11-18 (2004)

121. Kirchner C, Liedl T, Kudera S, Pellegrino T, Muñoz Javier A, Gaub HE, Stölzle S, Fertig N, Parak WJ: Cytotoxicity of colloidal CdSe and CdSe/ZnS nanoparticles. Nano Lett 5, 331-338 (2005)

122. Cho SJ, Maysinger D, Jain M, Roder B, Hackbarth S, Winnik FM: Long-term exposure to CdTe quantum dots causes functional impairments in live cells. Langmuir 23, 1974-1980 (2007)

123. Connor EE, Mwamuka J, Gole A, Murphy CJ, Wyatt MD: Gold nanoparticles are taken up by human cells but do not cause acute cytotoxicity. Small 1, 325-327 (2005)

124. Shenoy D, Fu W, Li J, Crasto C, Jones G, DiMarzio C, Sridhar S, Amiji M: Surface functionalization of gold nanoparticles using hetero-bifunctional poly (ethylene glycol) spacer for intracellular tracking and delivery. Int J Nanomedicine 1, 51 (2006)

125. Kawano T, Yamagata M, Takahashi H, Niidome Y, Yamada S, Katayama Y, Niidome T: Stabilizing of plasmid DNA in vivo by PEG-modified cationic gold nanoparticles and the gene expression assisted with electrical pulses. J Control Release 111, 382-389 (2006)

126. Hirsch LR, Stafford RJ, Bankson JA, Sershen SR, Rivera B, Price RE, Hazle JD, Halas NJ, West JL: Nanoshell-mediated nearinfrared thermal therapy of tumors under magnetic resonance guidance. Proc Natl Acad Sci U S A 100, 13549-13554 (2003)

127. Hainfeld JF, Slatkin DN, Smilowitz HM: The use of gold nanoparticles to enhance radiotherapy in mice. Phys Med Biol 49, N309 (2004)

128. Loo C, Lin A, Hirsch L, Lee MH, Barton J, Halas N, West J, Drezek R: Nanoshell-enabled photonics-based imaging and therapy of cancer. Technol Cancer Res Treat 3, 33-40 (2004)
129. O'Neal DP, Hirsch LR, Halas NJ, Payne JD, West JL: Photothermal tumor ablation in mice using near infrared-absorbing nanoparticles. Cancer Lett 209, 171-176 (2004)

130. Radt B, Smith TA, Caruso F: Optically addressable nanostructured capsules. Adv Mater 16, 2184-2189 (2004)

131. Niidome T, Yamagata M, Okamoto Y, Akiyama Y, Takahashi H, Kawano T, Katayama Y, Niidome Y: PEG-modified gold nanorods with a stealth character for in vivo applications. J Control Release $114,343-347$ (2006)

132. Su CH, Sheu HS, Lin CY: Nanoshell resonance imaging contrast agents. J Am Chem Soc 129, 2139-2146 (2006)

133. Bernardi RJ, Lowery AR, Thompson PA, Blaney SM, West JL: Immunonanoshells for targeted photothermal ablation in medulloblastoma and glioma: An in vitro evaluation using human cell lines. J Neurooncol 86, 165-172 (2008)

134. Stern JM, Stanfield J, Lotan Y, Park S, Hsieh JT, Cadeddu JA: Efficacy of laser-activated gold nanoshells in ablating prostate cancer cells in vitro. J Endourol 21, 939-943 (2007)

135. Lin W, Huang YW, Zhou XD, Ma Y: In vitro toxicity of silica nanoparticles in human lung cancer cells. Toxicol Appl Pharmacol $217,252-259$ (2006)

136. Chang JS, Chang KL, Hwang DF, Kong ZL: In vitro cytotoxicitiy of silica nanoparticles at high concentrations strongly depends on the metabolic activity type of the cell line. Environ Sci Technol 4l, 2064-2068 (2007)

137. Jin Y, Kannan S, Wu M, Zhao JX: Toxicity of luminescent silica nanoparticles to living cells. Chem Res Toxicol 20, 1126-1133 (2007)

138. Kumar MN, Sameti M, Mohapatra SS, Kong X, Lockey RF, Bakowsky U, Lindenblatt G, Schmidt CH, Lehr CM: Cationic silica nanoparticles as gene carriers: Synthesis, characterization and transfection efficiency in vitro and in vivo. J Nanosci Nanotechnol 4, 876-881 (2004)

139. Das P, Kumar K, Nambiraj A, Rajan R, Awasthi R, Dua K, Himaja M: Potential therapeutic activity of Phlogacanthus thyrsiformis Hardow (Mabb) flower extract and its biofabricated silver nanoparticles against chemically induced urolithiasis in male Wistar rats. Int J Biol Macromol 103, 621-629 (2017)

140. Bharali DJ, Siddiqui IA, Adhami VM, Chamcheu JC, Aldahmash AM, Mukhtar H, Mousa SA: Nanoparticle delivery of natural products in the prevention and treatment of cancers: Current status and future prospects. Cancers 3, 4024-4045 (2011)

141. Teskač K, Kristl J: The evidence for solid lipid nanoparticles mediated cell uptake of resveratrol. Int J Pharm 390, 61-69 (2010)

142. Jang M, Cai L, Udeani GO, Slowing KV, Thomas CF, Beecher CW, Fong HH, Farnsworth NR, Kinghorn AD, Mehta RG, Moon RC: Cancer chemopreventive activity of resveratrol, a natural product derived from grapes. Science 275, 218-220 (1997)

143. Bhattacharya S, Darjatmoko SR, Polans AS: Resveratrol modulates the malignant properties of cutaneous melanoma via changes in the activation and attenuation of the anti-apoptotic proto-oncogenic protein Akt/PKB. Melanoma Res 21, 180 (2011)

144. Kapadia GJ, Azuine MA, Tokuda H, Takasaki M, Mukainaka T, Konoshima T, Nishino H: Chemopreventive effect of resveratrol, sesamol, sesame oil and sunflower oil in the Epstein-Barr virus early antigen activation assay and the mouse skin two-stage carcinogenesis. Pharmacol Res 45, 499-505 (2002)

145. Ndiaye M, Philippe C, Mukhtar H, Ahmad N: The grape antioxidant resveratrol for skin disorders: Promise, prospects, and challenges. Arch Biochem Biophys 508, 164-170 (2011)

146. Bhat KP, Lantvit D, Christov K, Mehta RG, Moon RC, Pezzuto JM: Estrogenic and antiestrogenic properties of resveratrol in mammary tumor models. Cancer Res 61, 7456-7463 (2001) 
147. Lu R, Serrero G: Resveratrol, a natural product derived from grape, exhibits antiestrogenic activity and inhibits the growth of human breast cancer cells. J Cell Physiol 179, 297-304 (1999)

148. Shi Y, Yang S, Troup S, Lu X, Callaghan S, Park DS, Xing Y, Yang $\mathrm{X}$ : Resveratrol induces apoptosis in breast cancer cells by E2F1mediated up-regulation of ASPP1. Oncol Rep 25, 1713-1719 (2011)

149. Lee SJ, Kim MM: Resveratrol with antioxidant activity inhibits matrix metalloproteinase via modulation of SIRTl in human fibrosarcoma cells. Life Sci 88, 465-472 (2011)

150. Mousa SS, Mousa SS, Mousa SA: Effect of resveratrol on angiogenesis and platelet/fibrin-accelerated tumor growth in the chick chorioallantoic membrane model. Nutr Cancer 52, 59-65 (2005)

151. Chen Z, Jin K, Gao L, Lou G, Jin Y, Yu Y, Lou Y: Anti-tumor effects of bakuchiol, an analogue of resveratrol, on human lung adenocarcinoma A549 cell line. Eur J Pharmacol 643, 170-179 (2010)

152. Whyte L, Huang YY, Torres K, Mehta RG: Molecular mechanisms of resveratrol action in lung cancer cells using dual protein and microarray analyses. Cancer Res 67, 12007-12017 (2007)

153. Sengottuvelan M, Viswanathan P, Nalini N: Chemopreventive effect of trans-resveratrol-a phytoalexin against colonic aberrant crypt foci and cell proliferation in 1, 2-dimethylhydrazine induced colon carcinogenesis. Carcinogenesis 27, 1038-1046 (2005)

154. Mitchell SH, Zhu W, Young CY: Resveratrol inhibits the expression and function of the androgen receptor in LNCaP prostate cancer cells. Cancer Res 59, 5892-5895 (1999)

155. Stewart JR, Artime MC, O'Brian CA: Resveratrol: A candidate nutritional substance for prostate cancer prevention. J Nutr 133 2440S-2443S (2003)

156. Bishayee A, Politis T, Darvesh AS: Resveratrol in the chemoprevention and treatment of hepatocellular carcinoma. Cancer Treat Rev 36, 43-53 (2010)

157. Mbimba T, Awale P, Bhatia D, Geldenhuys WJ, Darvesh AS, Carroll RT, Bishayee A: Alteration of hepatic proinflammatory cytokines is involved in the resveratrol-mediated chemoprevention of chemically-induced hepatocarcinogenesis. Curr Pharm Biotechnol 13, 229-234 (2012)

158. Van Ginkel PR, Sareen D, Subramanian L, Walker Q, Darjatmoko SR, Lindstrom MJ, Kulkarni A, Albert DM, Polans AS: Resveratrol inhibits tumor growth of human neuroblastoma and mediates apoptosis by directly targeting mitochondria. Clin Cancer Res 13, 5162-5169 (2007)

159. Harikumar KB, Kunnumakkara AB, Sethi G, Diagaradjane P Anand P, Pandey MK, Gelovani J, Krishnan S, Guha S, Aggarwal BB: Resveratrol, a multitargeted agent, can enhance antitumor activity of gemcitabine in vitro and in orthotopic mouse model of human pancreatic cancer. Int J Cancer 127, 257-268 (2010)

160. Oi N, Jeong CH, Nadas J, Cho YY, Pugliese A, Bode AM, Dong Z: Resveratrol, a red wine polyphenol, suppresses pancreatic cancer by inhibiting leukotriene A4 hydrolase. Cancer Res 70, 9755-9764 (2010)

161. Dörrie J, Gerauer H, Wachter Y, Zunino SJ: Resveratrol induces extensive apoptosis by depolarizing mitochondrial membranes and activating caspase-9 in acute lymphoblastic leukemia cells. Cancer Res 61, 4731-4739 (2001)

162. Tsan MF, White JE, Maheshwari JG, Chikkappa G: Anti-leukemia effect of resveratrol. Leuk Lymphoma 43, 983-987 (2002)

163. Yao Q, Hou SX, He WL, Feng JL, Wang XC, Fei HX, Chen ZH: Study on the preparation of resveratrol chitosan nanoparticles with free amino groups on the surface. China J Chinese Materia Medica 31, 205-208 (2006)

164. Shao J, Li X, Lu X, Jiang C, Hu Y, Li Q, You Y, Fu Z: Enhanced growth inhibition effect of resveratrol incorporated into biodegradable nanoparticles against glioma cells is mediated by the induction of intracellular reactive oxygen species levels. Colloids Surf B Biointerfaces 72, 40-47 (2009)
165. Lu X, Ji C, Xu H, Li X, Ding H, Ye M, Zhu Z, Ding D, Jiang X, Ding X, Guo X: Resveratrol-loaded polymeric micelles protect cells from A $\beta$-induced oxidative stress. Int J Pharm 375, 89-96 (2009)

166. Guo L, Peng Y, Yao J, Sui L, Gu A, Wang J: Anticancer activity and molecular mechanism of resveratrol-bovine serum albumin nanoparticles on subcutaneously implanted human primary ovarian carcinoma cells in nude mice. Cancer Biother Radiopharm 25, 471-477 (2010)

167. Rozzi A, Nardoni C, Corona M, Restuccia MR, Falbo T, Lanzetta G: Weekly regimen of paclitaxel and carboplatin as first-line chemotherapy in elderly patients with stage IIIB-IV non small cell lung cancer (NSCLC): Results of a phase II study. J Chemother 22, 419-423 (2010)

168. Gupta SC, Kim JH, Prasad S, Aggarwal BB: Regulation of survival, proliferation, invasion, angiogenesis, and metastasis of tumor cells through modulation of inflammatory pathways by nutraceuticals. Cancer Metastasis Rev 29, 405-434 (2010)

169. Wu YY, Chang JY, Chao TY: Paclitaxel and carboplatin-induced complete remission in peritoneal carcinomatosis of unknown origin: A report of two cases and review of the literature. Tumori 96, 336-339 (2009)

170. George J, Banik NL, Ray SK: Combination of taxol and Bcl-2 siRNA induces apoptosis in human glioblastoma cells and inhibits invasion, angiogenesis and tumour growth. J Cell Mol Med 13, 4205-4218 (2009)

171. Fonseca C, Simoes S, Gaspar R: Paclitaxel-loaded PLGA nanoparticles: Preparation, physicochemical characterization and in vitro anti-tumoral activity. J Control Release 83, 273-286 (2002)

172. Feng SS, Mu L, Win KY, Huang G: Nanoparticles of biode gradable polymers for clinical administration of paclitaxel. Curr Med Chem 11, 413-424 (2004)

173. Sahoo SK, Ma W, Labhasetwar V: Efficacy of transferringconjugated paclitaxel-loaded nanoparticles in a murine model of prostate cancer. Int J Cancer 112, 335-340 (2004)

174. Sharma A, Chhikara S, Ghodekar S, Gawande R, Namdeo A, Mahadi K, Fulzele D: Camptothecin: Discovery and developments. Pharmacogn Rev 2, 219 (2008)

175. Onishi H, Machida Y, Machida Y: Antitumor properties of irinotecan-containing nanoparticles prepared using poly (DL-lactic acid) and poly (ethylene glycol)-block-poly (propylene glycol)block-poly (ethylene glycol). Biol Pharm Bull 26, 116-119 (2003)

176. McCarron PA, Marouf WM, Quinn DJ, Fay F, Burden RE, Olwill SA, Scott CJ: Antibody targeting of camptothecin-loaded PLGA nanoparticles to tumor cells. Bioconjugate Chem 19, 1561-1569 (2008)

177. Min KH, Park K, Kim YS, Bae SM, Lee S, Jo HG, Park RW, Kim IS, Jeong SY, Kim K, Kwon IC: Hydrophobically modified glycol chitosan nanoparticles-encapsulated camptothecin enhance the drug stability and tumor targeting in cancer therapy. J Control Release 127, 208-218 (2008)

178. Aggarwal BB, Kumar A, Bharti AC: Anticancer potential of curcumin: Preclinical and clinical studies. Anticancer Res 23, 363-398 (2003)

179. Bisht S, Feldmann G, Soni S, Ravi R, Karikar C, Maitra A, Maitra A: Polymeric nanoparticle-encapsulated curcumin ("nanocurcumin"): A novel strategy for human cancer therapy. J Nanobiotechnol 5, 3 (2007)

180. Sahu A, Bora U, Kasoju N, Goswami P: Synthesis of novel biodegradable and self-assembling methoxy poly (ethylene glycol)-palmitate nanocarrier for curcumin delivery to cancer cells. Acta Biomater 4, 1752-1761 (2008)

181. Thangapazham RL, Puri A, Tele S, Blumenthal R, Maheshwari RK: Evaluation of a nanotechnology-based carrier for delivery of curcumin in prostate cancer cells. Int J Oncol 32, 1119-1123 (2008) 
182. Das RK, Kasoju N, Bora U: Encapsulation of curcumin in alginate-chitosan-pluronic composite nanoparticles for delivery to cancer cells. Nanomedicine 6, 153-160 (2010)

183. Merrell JG, McLaughlin SW, Tie L, Laurencin CT, Chen AF, Nair LS: Curcumin-loaded poly ( $\varepsilon$-caprolactone) nanofibres: Diabetic wound dressing with anti-oxidant and anti-inflammatory properties. Clin Exp Pharmacol Physiol 36, 1149-1156 (2009)

184. Li J, Wang Y, Yang C, Wang P, Oelschlager D, Zheng Y, Tian DA, Grizzle W, Buchsbaum D, Wan M: Polyethylene glycosylated curcumin conjugate inhibits pancreatic cancer cell growth through inactivation of Jabl. Mol Pharmacol 76, 81-90 (2009)

185. Shaikh J, Ankola DD, Beniwal V, Singh D, Kumar MR: Nanoparticle encapsulation improves oral bioavailability of curcumin by at least 9-fold when compared to curcumin administered with piperine as absorption enhancer. Eur J Pharm Sci 37 , 223-230 (2009)

186. Desai NP, Tao C, Yang A, Louie L, Yao Z, Soon-Shiong P, Magdassi S: Protein stabilized pharmacologically active agents, methods for the preparation thereof and methods for the use thereof. US patent 6749868BI (2004)

187. Au JL, Wientjes MG: Tumor targeting drug-loaded particles. US patent US2006034925Al (2006)

188. Liu Y: Special preparation of anticancer drugs made by novel nanotechnology. US patent US2004192641Al (2004)

189. Sabel BA, Kreuter J, Gelperina S, Schroeder U: Use of drugloaded nanoparticles for the treatment of cancers. WO0074658Al (2000)

190. Barchi JJ Jr, Rittenhouse-olson K, Svarovsky S: Carbohydrate antigen-nanoparticle conjugates and uses thereof as antimetastatic agents in treating cancer. US patent US20070275007 Al (2007)

191. Shefer A, Shefer S: $\mathrm{pH}$ triggered site specific targeted controlled drug delivery system for the treatment of cancer. US patent US2004234597Al (2004)

192. Wood RW, Wiedmann TS, DeCastro L: Aerosols containing beclomethazone nanoparticle dispersions. US patent 5747001 (1998)
193. Tofovic SP, Jackson EK: Estradiol metabolites for the treatment of pulmonary hypertension. US patent 7192941 (2007)

194. Bednarski MD, Guccione S, Li KC: Use of targeted cross-linked nanoparticles for in vivo gene delivery. US patent US2003013674Al (2003)

195. Sui Y, Ye Q, Wu D: Method for preparing broad spectrum genetically engineered nano vaccine for malignant tumour. CN1528452A (2004)

196. Reszka R, Brandl M, Fichtner I, Warnke G: Liposome encapsulated Taxol, its preparation and its use. US patent 6090955 (2000)

197. Esenaliev RO: Radiation and nanoparticles for enhancement of drug delivery in solid tumors. US patent 165440A (2000)

198. Handy ES, Ivkov R, Ellis-Busby D, Foreman A, Braunhut SJ, Gwost DU, Ardman B, Jahngen EGE: Thermotherapy via targeted delivery of nanoscale magnetic particles. WO03022360A2 (2003)

199. Jain AR, Wei L, Swanson J: Solid dose form of nanoparticulate naproxen. US patent 6165506 (2000)

200. Russell-Jones GJ, McEwan JF: Amplification of folate-mediated targeting to tumor cells using nanoparticles. EP1206251Al (2002)

201. Langecker P, Steiert M, Hino T, Scicinksi J, Paulvannan K: Composite nanoparticles and uses thereof. WO2017156191 (2017)

202. Mao HQ, Williford JM, Archang M, Minn I, Ren Y, Santos JL: Compositions of nucleic acid containing nanoparticles for in vivo delivery. US20160331845 (2016)

203. Nicolosi R, Shea T: Anti-oxidant synergy formulation nanoemulsions to treat cancer. US20150079176 (2015)

204. Wright J: Docetaxel polymeric nanoparticles and methods of treating cancers using same. US20160151298 (2016)

205. Wang C, Zhen M, Shu C, Wang T, Li J, Zhang G: A method for treating cancer based on metallofullerene monocrystalline nanoparticles that specifically disrupt tumor blood vessels. EP313051 (2017)

206. Bhatia P, Vasaikar S, Wali A: A landscape of nanomedicine innovations in India. Nanotechnol Rev 7, 131-148 (2018) 